\title{
Survey and assessment of post volcanic activities of a young caldera lake, Lake Cuicocha, Ecuador
}

\author{
G. Gunkel ${ }^{1}$, C. Beulker ${ }^{1}$, B. Grupe ${ }^{2}$, and F. Viteri $^{3}$ \\ ${ }^{1}$ Berlin University of Technology, Dept. of Water Quality Control, Germany \\ ${ }^{2}$ Berlin University of Technology, Dept. of Water, Environment and Marine Science and Technology (VWS), Germany \\ ${ }^{3}$ Universidad Central, Faculty of Geology, Mines, Petrol and Environmental Science, Quito, Ecuador
}

Received: 13 October 2008 - Revised: 20 April 2009 - Accepted: 20 April 2009 - Published: 8 May 2009

\begin{abstract}
Cuicocha is a young volcano adjacent to the inactive Pleistocene Cotacachi volcano complex, located in the western cordilleras of the Ecuadorian Andes. A series of eruptions with intensive ash emission and collapse of the caldera occurred around 4500-3000 y BP. A crater $3.2 \mathrm{~km}$ in diameter and a maximum depth of $450 \mathrm{~m}$ was formed. Further eruptions of the volcano occurred $1300 \mathrm{y} \mathrm{BP}$ and formed four smaller domes within the caldera. Over the last few hundred years, a caldera lake has developed, with a maximum depth of $148 \mathrm{~m}$. The lake water is characterized by sodium carbonate with elevated concentrations of manganese, calcium and chloride. Nowadays, an emission of gases, mainly $\mathrm{CO}_{2}$, and an input of warm spring water occur in Lake Cuicocha. The zone of high activity is in the western basin of the lake at a depth of $78 \mathrm{~m}$, and continuous gas emissions with sediment resuspension were observed using sonar. In the hypolimnion of the lake, $\mathrm{CO}_{2}$ accumulation occurs up to $0.2 \%$ saturation, but the risk of a limnic eruption can be excluded at present. The lake possesses monomictic stratification behaviour, and during overturn an intensive gas exchange with the atmosphere occurs. Investigations concerning the sedimentation processes of the lake suggest only a thin sediment layer of up to $10-20 \mathrm{~cm}$ in the deeper lake basin; in the western bay, in the area of gas emissions, the lake bottom is partly depleted of sediment in the form of holes, and no lake colmation exists. Decreases in the lake water level of about $30 \mathrm{~cm} \mathrm{y}^{-1}$ indicate a percolation of water into fractures and fissures of the volcano, triggered by a nearby earthquake in 1987.
\end{abstract}

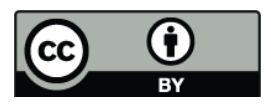

Correspondence to: G. Gunkel (guenter.gunkel@tu-berlin.de)

\section{Introduction}

Lakes, built up in a crater or caldera, are strongly influenced by volcanic or post-volcanic activities such as gas emission and hydrothermal water springs or by deep seated geothermal systems. Thus, different volcanic lake types are formed, and have been classified by their water physico-chemical constraints by Pasternack and Varekamp (1997). These authors distinguished volcanic lakes with different levels of activity, namely cool to hot acid-brine lakes, reduced to oxidized acid-saline lakes, acid-sulphate lakes and bursting to buoyant plume bicarbonate lakes; only neutral dilute volcanic lakes do not show any activity. Interaction of a rising fragmented magma with the lake water can produce violent hydromagmatic explosions that may generate very hazardous base surges and a huge emission of fine ash. In lakes where the water level is near to the rim, water overflow may occur with generation of lahars and floods.

An extensive survey of lake eruptions is given by Mastin and Witter (2000), listing in total 47 volcanoes with 275 lake eruptions; they are dominated by numerous events of relatively few volcanoes. Base surges, lahars and floods have been devastating during some eruptions, but up to now no specific conditions are recognized to produce these hazards (Christenson, 2000; Matthews et al., 2002). The evaluation of the natural hazard from volcanic lakes should be focus of investigations due to the devastation of eruptions through such lakes.

In many volcanic areas and geothermal fields, high emissions of $\mathrm{CO}_{2}$ gas occur and the $\mathrm{CO}_{2}$ is dissolved in lake water (Martini, 1993; Chiodini and Frondini, 2001). The accumulation of $\mathrm{CO}_{2}$ in volcanic lakes is a process well known since the disaster of Lake Nyos, which was followed by intensive international research to analyze the phenomenon of gaseous eruption (Le Guern and Sigvaldason, 1989, 1990; Evans et al., 1994; Kusakabe et al., 2000; Kling et al., 2005). Under pressure, large amounts of $\mathrm{CO}_{2}$ are soluble in water,

Published by Copernicus Publications on behalf of the European Geosciences Union. 
and at a depth of $100 \mathrm{~m}$ up to 151 of pure $\mathrm{CO}_{2}$ gas can be dissolved in 11 of water at equilibrium (Colt, 1984). Consequently, a significant level of $\mathrm{CO}_{2}$ accumulation can occur only in deep volcanic lakes. This $\mathrm{CO}_{2}$ accumulation is strongly influenced by limnological processes such as thermal or chemical stratification of the water body (with inhibition of lake mixing and $\mathrm{CO}_{2}$ degassing to the atmosphere), chemical reactions of $\mathrm{CO}_{2}$ such as the formation and precipitation of siderite $\left(\mathrm{FeCO}_{3}\right)$ or calcite/aragonite $\left(\mathrm{CaCO}_{3}\right)$ and the bacterial reduction of $\mathrm{CO}_{2}$ to $\mathrm{CH}_{4}$ (Schoell et al., 1988). $\mathrm{Up}$ to now, the processes of $\mathrm{CO}_{2}$ input in volcanic lakes and the possible degassing or eruption mechanisms are not yet sufficiently understood, and many of the deep caldera lakes with regard to their eruption risk have not yet been studied. Worldwide 75 calderas contain one or more lakes, 24 caldera lakes are known to be $>100 \mathrm{~m}$ depth, but for most the depth is unknown (Larson, 1989).

Many Andean crater lakes are poorly investigated, although this is a region with a great number of active volcanoes. In Ecuador, two lakes are known to be active volcanic lakes, the Quilotoa (Aguilera et al., 2000) and the Cuicocha (von Hillebrandt and Hall, 1988), located in the high Andean region $>3000 \mathrm{~m}$ a.s.l.; both volcanoes have formed large and deep caldera lakes.

The focus of this study was the integrative evaluation of the Cuicocha crater lake to obtain a better understanding of the lake evolution, the $\mathrm{CO}_{2}$ emissions and the possible hazards of caldera lakes (Gunkel et al., 2008).

\section{Regional setting}

Lake Cuicocha is a caldera lake in the western cordilleras of the Andes, located about $100 \mathrm{~km}$ north of Quito, Ecuador, near Otavalo (Fig. 1). It is situated $3072 \mathrm{~m}$ a.s.l., has a diameter of $3.2 \mathrm{~km}$, a surface area of $3.78 \mathrm{~km}^{2}$ and a maximum depth of $148 \mathrm{~m}$; two islands, which represent the last main volcanic events form the central part of the caldera, Island Yerovi $\left(0.26 \mathrm{~km}^{2}\right)$ and Island Wolf $\left(0.41 \mathrm{~km}^{2}\right.$, Fig. 2$)$.

Cuicocha is a parasitic volcano of the Cotacachi volcano, which was active in the Pleistocene period (Fig. 3); Cotacachi is situated in the Otavalo-Umpalà fracture zone (Hanuš, 1987). Geochemical and mineralogical investigations do not indicate that both volcanoes were fed by the same type of magma (Gunkel et al., 2009b). Cuicocha began its activity with a series of eruptions 4490-2990 y BP, including lava flows and ash falls with depositions of $150 \mathrm{~m}$ thickness (Fig. 3). The collapse of the dome with the formation of a caldera after the 2990 y BP eruption (Mothes and Hall, 1991) was followed by further eruptions which finally built up four domes within the caldera (1350-1230 BP; Gunkel et al., 2009b). The absence of volcanic glass in the erupted fresh lava flow of the Yerovi and Wolf domes indicate that the lava had no contact to water; the lake formation began later, after the caldera was partly filled with slope debris from

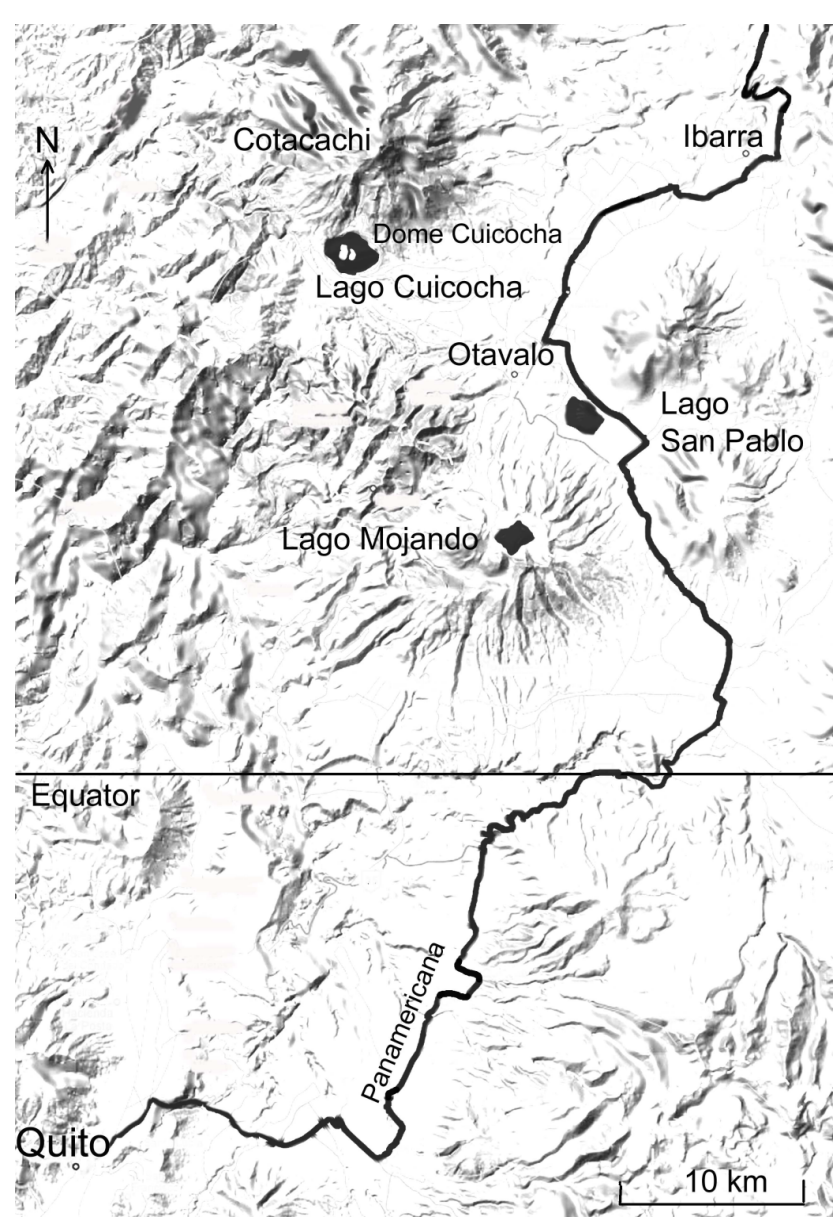

Fig. 1. Northern part of Ecuador with the crater lakes Cuicocha and Mojanda and the glacial formed Lake San Pablo.

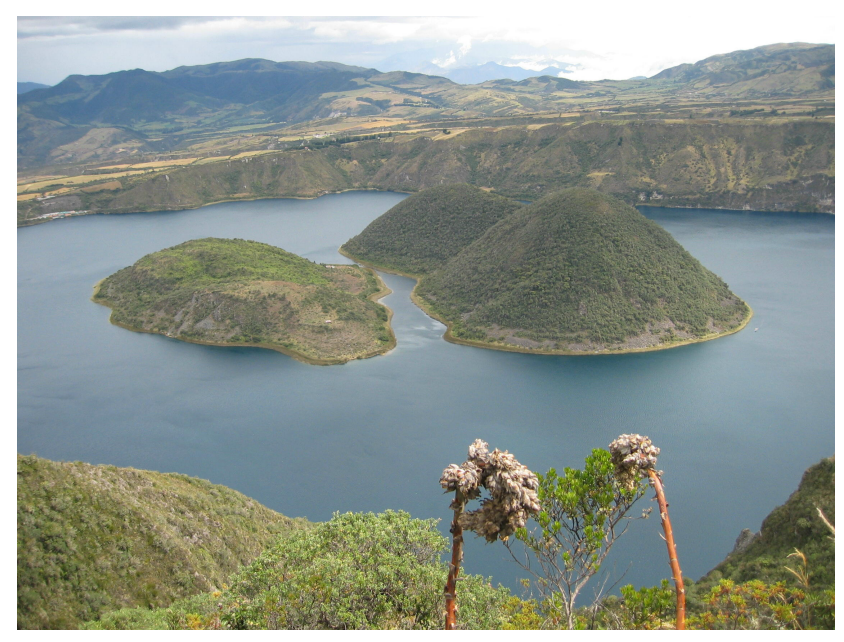

Fig. 2. Lake Cuicocha with domes Yerovi (left) and Wolf (right).

the crater walls and sediments from the catchment area, and fractures and fissures were clogged, approximately 1000500 years ago. 
The water basin of Lake Cuicocha is formed by the flanks of Cotacachi volcano (Fig. 3), the soils consist of volcanic deposits mainly andesite with a high $\mathrm{SiO}_{2}(57.4-61.3 \%)$ and $\mathrm{Al}_{2} \mathrm{O}_{3}(16.8-18.3 \%)$ content and are of remarkably uniform composition, presumably reflecting a steady state process of magma genesis over a long period of time. The investigated rocks from Cotacachi are medium calc-alcalic with a $\mathrm{K}_{2} \mathrm{O}$ content that ranges between $1.1-1.3 \%$ and $\mathrm{Na}_{2} \mathrm{O}$ content between 3.4-3.9\% (Gunkel et al., 2009b).

The soils are in an early stage of development with a low clay content classified as andisols with paramo vegetation. Allophane and Al-humus complexes dominate the colloidal fraction. The topsoils are rich in organic matter because the cold temperatures favour an accumulation of organic carbon (Zehetner et al., 2003).

Two other lakes, located near to the Cuicocha volcano, were used as reference systems (Fig. 1). Lake Mojanda is a caldera lake of the Mojanda volcano, which was active 43000 y BP (Robin et al., 1997); the caldera lake has a depth of $80 \mathrm{~m}$ with a maximum diameter of $2.6 \mathrm{~km}$. Lake San Pablo is a $35 \mathrm{~m}$ deep glacial lake on the flanks of the volcano Imbabura (Casallas and Gunkel, 2002; Gunkel and Casallas, 2002; Casallas, 2005).

\section{Materials and methods}

\subsection{Digital elevation model (DEM)}

A digital elevation model (DEM) including the lake basin, was developed with data from the IDR, France, based on digitalized topographic maps 1:50 000 (Souris, IRD, France), together with GPS field data of the crater rim, and with about 1250 data points in 100 profiles from the lake. Bathymetry was investigated using sonar (Garmin Fishfinder 250 C) with a double frequency $(50 / 200 \mathrm{kHz})$ and a GPS (Garmin 60 CS) for localisation. The DEM was developed using ArcGis 9.0 with Spatial Analyt software, and a horizontal resolution of $10 \mathrm{~m}$ was reached.

\subsection{Meteorological data}

The lake's water level was registered using an installed level indicator over a three year period (2004-2006), precipitation was determined by a simple rain water collector, and evaporation was registered in a water filled tank, both were installed near the lake shore on a house roof in the shade. A direct measurement of evaporation by a tank in the lake was not possible due to frequent theft. Air temperature was measured daily with a minimum/maximum thermometer.

\subsection{Water analyses}

Lake Cuicocha was investigated by a regular monitoring program during the years 2004-2006, every year there were two investigation periods, February to April (rainy period) and

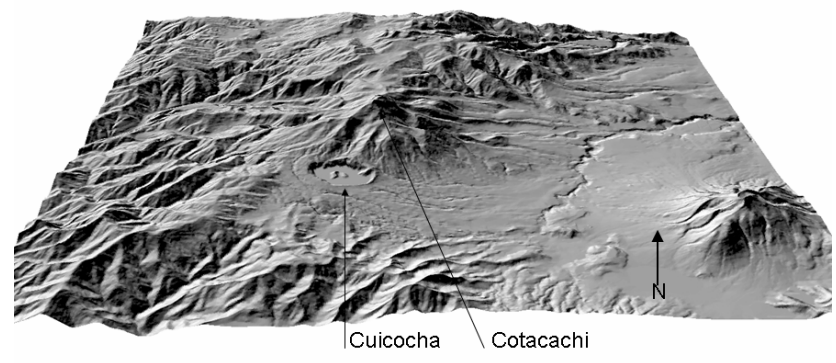

Fig. 3. DEM of Cotacachi volcano complex with the parasitic Cuicocha volcano and the caldera lake (DEM development with data of Souris, IRD, France), scale: the diameter of Lake Cuicocha is $3 \mathrm{~km}$.

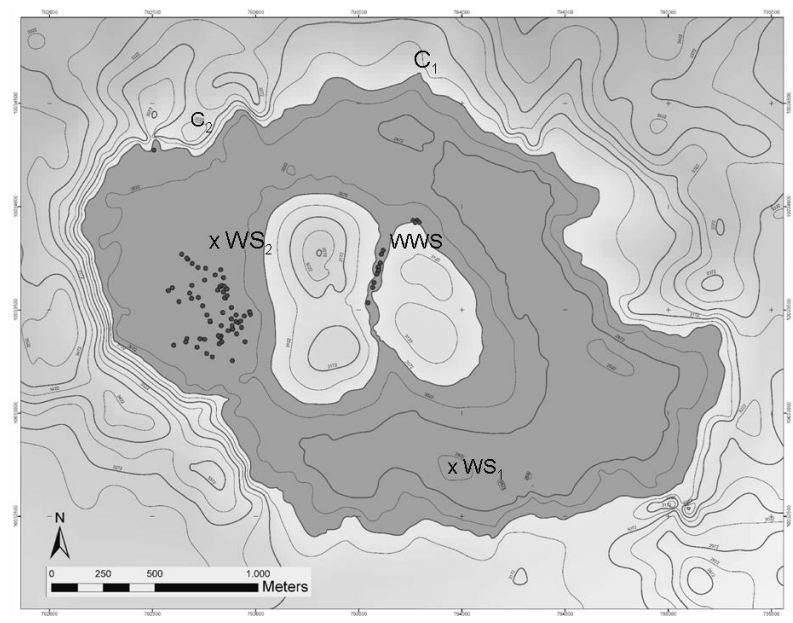

Fig. 4. Bathymetric map of Lake Cuicocha, based on 100 profiles with 1.250 data points, given are the $50 \mathrm{~m}$ contour lines, lake level $3072 \mathrm{~m}$ a.s.1.; WS $=$ water sampling positions; $\mathrm{C}=$ water inflow by cascades; WWS $=$ warm water springs, $\bullet=$ areas with volcanic gas emissions.

July to October (dry period). Different positions were investigated, the deepest $148 \mathrm{~m}$ area (in total 17 profiles) and the western basins $78 \mathrm{~m}$ depth (4 profiles) as well as 6 other profiles at different places (Fig. 4). Water chemistry data include 6 vertical profiles (in 08/03, 09/03, 03/03, 08/04, 03/05, $08 / 05$ ), and lake profiler data diagrams ( $\mathrm{T}, \mathrm{pH}$, cond., $\mathrm{E}_{7}$ ) are based on 10 profiles (in 08/03, 09/03, 03/04, 08/04, 03/05, 08/05, 04/06). Too horizontal drifting of the lake profiler near the lake bottom was done frequently.

Sampling in the nearby Mojanda crater lake was carried out in August 2003, and investigation of Lake San Pablo was done in 1998-1999 by an intensive monitoring every 23 weeks (Gunkel and Casallas 2002; Casallas and Gunkel, 2002).

Temperature, $\mathrm{pH}$, conductivity, $\mathrm{CO}_{2}$ and redox potential $\left(\mathrm{E}_{7}\right)$ were determined using a lake profiler (Ocean Seven 316 with $\mathrm{CO}_{2}$ probe, Idronaut, Italy). The data acquisition was 


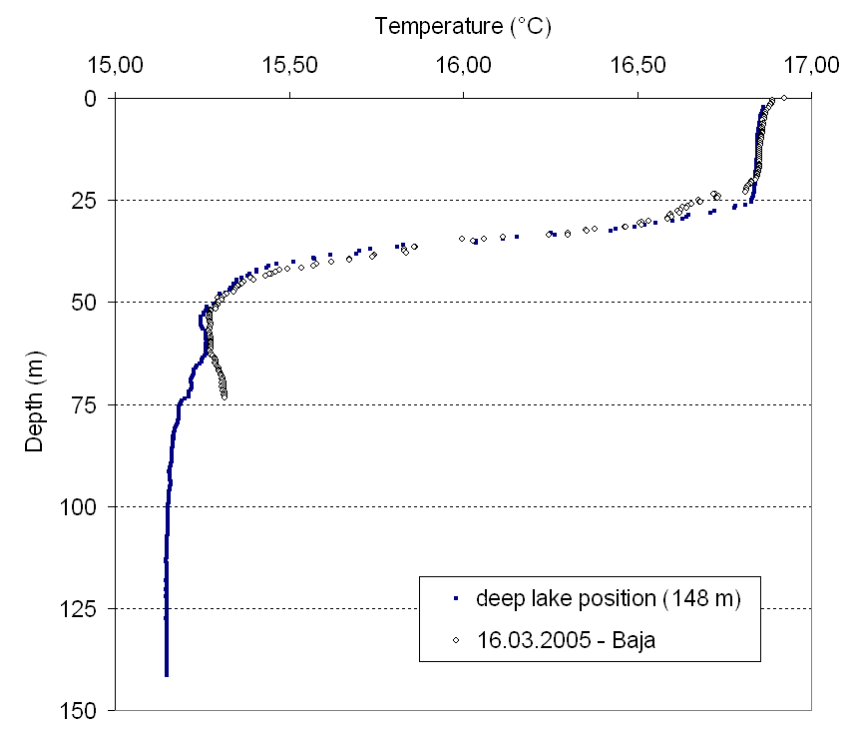

Fig. 5. Temperature profiles in the $148 \mathrm{~m}$ and $78 \mathrm{~m}$ basins, 16 March 2005, during thermal stratification period.

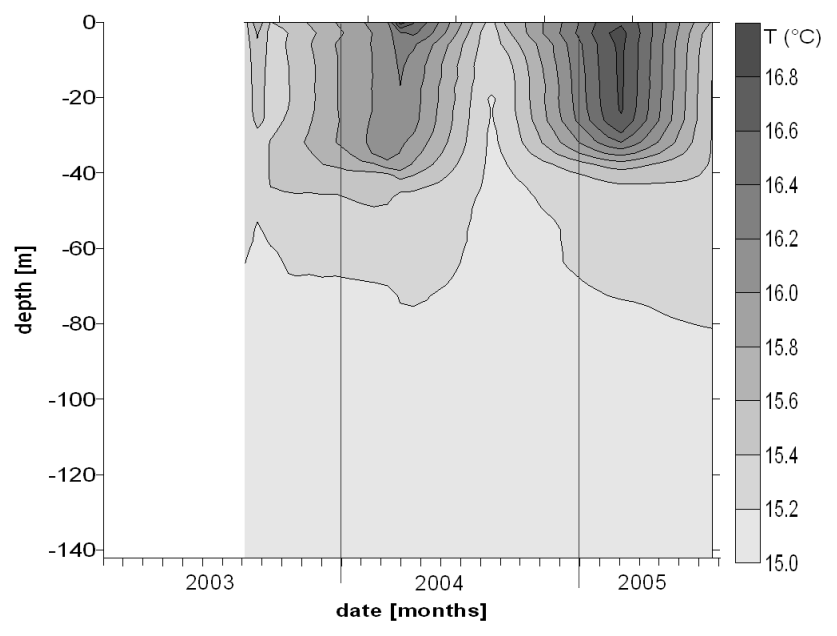

Fig. 6. Temperature isopleths of Lake Cuicocha with overturn period in June to September, $148 \mathrm{~m}$ position.

linear every $1.0 \mathrm{~m}$, a few high resolution profiles were taken every $0.2 \mathrm{~m}$. The accuracy of the probes was extremely high and within values for temperature $0.003^{\circ} \mathrm{C}$, for $\mathrm{pH} 0.01 \mathrm{pH}$ units and for redox potential $1 \mathrm{mV}$ were determined. The $\mathrm{CO}_{2}$ probe was not stable over daily periods, and it was necessary to calibrate the probe before use. Oxygen within the carbonate precipitations was determined using optical oxygen sensors of $\emptyset 2 \mathrm{~mm}$ with a Fibox 3 oxygen meter (PreSens, Germany).

The density of the water was calculated under consideration of salinity, local pressure and temperature using the formula of Chen and Millero (1986) for natural waters and is expressed as $\rho_{\text {(S,T,Psurface) }}\left(=\right.$ density $\left.1000 \mathrm{~kg} / \mathrm{m}^{3}\right)$; salinity was calculated by the total ionic content. Calcium carbonate saturation index was calculated with the MINEQL 4.5 program.

Water samples were taken using a Ruttner type water sampler (Hydrobios, Germany). Depth of water sampling as well as of other equipment was controlled by sonar (Garmin Fishfinder 250 C) which enabled a high precision for data registration near the sediment. For cation and anion analyses, the water was filtered immediately after sampling into HDPE bottles, using $0.45 \mu \mathrm{m}$ polyacetate filters. Water was preserved with $\mathrm{HNO}_{3}$, respectively $\mathrm{HCl}$ (at $\mathrm{pH} \sim 1$ ). Samples of suspended material were obtained by filtration of $250 \mathrm{~mL}$ lake water using $0.4 \mu \mathrm{m}$ polycarbonate filters (Nuclepore) for Scanning Electron Microscopy with Energy Dispersive Spectroscopy (SEM-EDS) analyses. The wet polycarbonate filters were stored in plastic bags with taps soaked with formaldehyde (37\%) for preservation.

On Island Yerovi, the warm water spring was sampled by a small well with $0.5 \mathrm{~m}$ depth.

The data base for the lake water chemistry includes 6 profiles (36 data points), isopleths diagrams $\left(\mathrm{T}, \mathrm{pH}, \mathrm{E}_{7}\right)$ are based on 10 vertical profiles with 2275 data points, Cacarbonate saturation index includes 69 data points, and $\mathrm{CO}_{2}$ concentration is based on 86 analyses.

$\mathrm{CO}_{2}, \mathrm{HCO}_{3}^{-}$and $\mathrm{CO}_{3}^{2-}$ determinations were carried out on the sampling day according to the German Standard Methods for $\mathrm{pK}_{a}$ and $\mathrm{pK}_{b}$ determination (DEV, 2005). Water chemistry of the non-reactive cations and anions was investigated in the laboratory of the Technical University of Berlin, Department of Water Quality Control, Germany, using preserved water samples.

Dissolved as well as total cations $\mathrm{Ca}^{2+}, \mathrm{Na}^{+}, \mathrm{Mg}^{2+}, \mathrm{K}^{+}$, $\mathrm{As}^{3+}, \mathrm{Al}^{3+}\left(50-200 \mu \mathrm{g} \mathrm{L}^{-1}\right)$ and $\mathrm{Fe}^{2+} / \mathrm{Fe}^{3+}\left(2-50 \mathrm{mg} \mathrm{L}^{-1}\right)$ were analyzed by flame atomic absorption spectroscopy (AAS; GBC Scientific Equipment, Pty. Ltd. Victoria, Australia); for some cation analyses a graphite ASS (Varian Spectra A-400) was used $\left(\mathrm{Li}^{+}, \mathrm{Al}^{3+}\left[10-50 \mu \mathrm{g} \mathrm{L}^{-1}\right]\right.$, $\mathrm{Fe}^{2+} / \mathrm{Fe}^{3+}\left[10-50 \mu \mathrm{g} \mathrm{L}^{-1}\right]$ and $\left.\mathrm{Mn}^{2+}\right)$. The determination of $\mathrm{Al}$ was recognized to be critical, because settling of fine suspended precipitates occurred in the GC vials, thus only freshly diluted samples were injected by hand immediately after preparation into the AAS analyser (Gunkel et al., 2009a). Anions $\mathrm{Cl}^{-}, \mathrm{SO}_{4}^{2-}, \mathrm{PO}_{4}^{3-}, \mathrm{NO}_{3}^{-}$were analyzed using an ionic chromatograph (AS 50 Dionex) with CD 20 detector, GD 50 gradient pump and AS 11 column for separation. Boron was determined photometrically (DEV, 1981; Dr. Lange test LCK 307) with a detection limit of $0.05 \mathrm{mg} \mathrm{L}^{-1}$.

\subsection{Gas analyses}

Gas sampling was done directly with gas chromatography (GC) vials at the lake shore and on Island Yerovi. Analyses of $\mathrm{CO}_{2}, \mathrm{CO}, \mathrm{O}_{2}, \mathrm{~N}_{2}, \mathrm{~N}_{2} \mathrm{O}$, and $\mathrm{CH}_{4}$ were carried out using a GC with flame ionisation detection (FID) and 
thermal conductivity detection (TCD) at the Leibniz-Institute of Freshwater Ecology and Inland Fisheries, Berlin, Germany, a few weeks after sampling. Vial storage and gas filling of the syringe was done underwater due to the low pressure in the vials. Detection of gas emissions was done by sonar, a method applied sometimes in limnological research (Ostrovsky, 2003; Ostrovsky et al., 2008) using a Garmin Fishfinder $250 \mathrm{C}$ (double frequency, $50 / 200 \mathrm{kHz}$ ), the boat was not moved, so that the rising gas bubbles gave a diagonal line signal. The signal could be verified by visual gas bubbles at the lake surface.

\subsection{Sediment analyses}

Suspended material was collected using 8 sediment traps, $8 \mathrm{~cm} \emptyset, 50 \mathrm{~cm}$ length, which were exposed in the lake for two periods, each one for 2 weeks at depths of 15, 30, 50 and $70 \mathrm{~m}$ in the western bay of the lake. Samples were preserved with $4 \%$ glutaraldehyde solution for further investigation.

For water depth determination, Garmin Fishfinder 250 C sonar was used, the application of sonar allowed detection of the lake floor as well as recognition of resuspended sediments as a consequence of gas eruptions and gave an indication of sediment density.

A Sony HCR-HC16E digital video camera was modified as an underwater camera, protected by a purpose built aluminium housing, equipped with 4 underwater lamps type Nemo 8C Xenon, 14 watt. With this camera, the sediment type and gas emissions with sediment resuspension were registered as well as the penetration of the sediment core sampler into the sediment was studied.

Sediment samples were collected by an Ekmann-Birge sediment sampler and a sediment gravity corer, $5 \mathrm{~cm} \emptyset$ with a sediment capturer. Sediment sampling was recognized to be very difficult due to only a thin sediment layer on the stony floor and to sediment oversaturation by gases, which led to the loss of sediments while degassing during lifting of the equipment.

Sediment samples were prepared using an $\mathrm{HCl} / \mathrm{HNO}_{3}$ acid digestion method (VDLUFA, 1991), and then analyzed using the above mentioned analytical methods.

\section{Results}

\subsection{Lake morphology}

The watershed of Lake Cuicocha is very small and amounts to $18.2 \mathrm{~km}^{2}$, extending onto the flanks of Cotacachi volcano (Fig. 3). Most of the caldera flanks and of the islands have steep inclinations, and a flank inclination mapping based on the DEM model showed for about $75 \%$ of the shore line inclination areas $>45^{\circ}$, only the south-east shore of the lake has small inclinations with $10-25^{\circ}$. The crater rim consists of

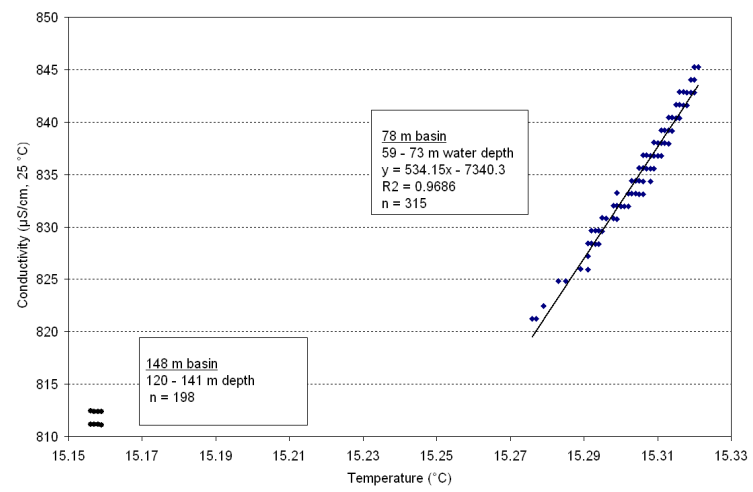

Fig. 7. Relationship of temperature and conductivity of Lake Cuicocha near lake bottom at $59-73 \mathrm{~m}$ depth $(78 \mathrm{~m}$ basin) and at 120-141 m depth (148 m basin).

very young eruptive material with little consolidation, but existing vegetation reduces the hazard of landslides. However, earthquakes, common in the area (6 earthquakes in 140 years were registered by a chronicler in Otavalo), can trigger rock falls and landslides; during the earthquake in 5 March 1987 (Mercalli mg. VII), that affected the district of Ibarra, a landslide transported large amounts of volcanic debris of some $10000 \mathrm{~m}^{3}$ into the crater lake.

The bathymetric map shows two separate lake basins, one with the maximum depth of $148 \mathrm{~m}$ extending east of the islands, and the other with a depth of $78 \mathrm{~m}$, situated in the western part of the lake. The declination of the lake's littoral zone is extremely high, and in some parts of the crater rim, a water depth of $50 \mathrm{~m}$ is reached only $20 \mathrm{~m}$ from the shoreline (Fig. 4).

Lake Cuicocha has no visible continuous inflow, two cascades are served by rain and drainage water and discharge into the lake at the steep northern flank of the crater rim (Fig. 4); no direct outflow exists, but one nearby spring is fed by the lake (flow rate $\sim 1.5 \mathrm{~L} \mathrm{~s}^{-1}$ ).

\subsection{Thermal stratification}

The temperature in Lake Cuicocha (148 m basin) was characterized by a thermal stratification with very small temperature differences of about $2^{\circ} \mathrm{C}$ between the epilimnion, which stretched down to $25 \mathrm{~m}$ and the hypolimnion below $50 \mathrm{~m}$; the metalimnion was expended and stretched down from 25 to $50 \mathrm{~m}$ (Fig. 5). However, this temperature difference was sufficient to build up a relatively weak thermal stratification, confirmed by the density calculation $(\Delta \rho=0.2795$, in March 2005, Table 1a). The stratification of the lake was confirmed by a corresponding stratification of some physical and chemical parameters ( $\mathrm{pH}, \mathrm{E}_{7}$, cond., $\mathrm{CO}_{2}$; Table 1a).

The lake circulation is characterized by a monomictic behaviour, overturn occurs in June to September, due to strong winds passing the lake through a shallow caldera flank, 
Table 1a.Vertical water physical and chemical parameters of Lake Cuicocha, $148 \mathrm{~m}$ basin, 17 March 2005.

\begin{tabular}{|c|c|c|c|c|c|c|c|c|c|c|c|c|c|c|}
\hline Depth & $\begin{array}{l}\text { Temp. } \\
{ }^{\circ} \mathrm{C}\end{array}$ & $\mathrm{pH}$ & $\begin{array}{l}\text { Cond } \\
{\left[25^{\circ} \mathrm{C}\right]} \\
\mu \mathrm{S} \mathrm{cm}^{-1}\end{array}$ & $\begin{array}{l}\text { Density } \\
\rho_{(\mathrm{S}, \mathrm{T}, \mathrm{Po})} \\
\mathrm{kg} \mathrm{m}^{-3}\end{array}$ & $\begin{array}{l}\mathrm{E}_{7} \\
\mathrm{mV}\end{array}$ & $\begin{array}{l}\mathrm{O}_{2} \\
\mathrm{mg} \mathrm{l}^{-1}\end{array}$ & $\begin{array}{l}\mathrm{CO}_{2} \\
\mathrm{mgl}^{-1}\end{array}$ & $\begin{array}{l}\mathrm{HCO}^{3+} \\
\mathrm{mgl}^{-1}\end{array}$ & $\begin{array}{l}\mathrm{CO}_{3}^{2-} \\
\mathrm{mgl}^{-1}\end{array}$ & $\begin{array}{l}\mathrm{Cl}^{-} \\
\mathrm{mgl}^{-1}\end{array}$ & $\begin{array}{l}\mathrm{SO}_{4}^{2-} \\
\mathrm{mg} \mathrm{l}^{-1}\end{array}$ & $\begin{array}{l}\mathrm{NH}_{4}-\mathrm{N} \\
\mathrm{mg} \mathrm{l}^{-1}\end{array}$ & $\begin{array}{l}\mathrm{N}_{\text {tot }} \\
\mathrm{mg} \mathrm{1}^{-1}\end{array}$ & $\begin{array}{l}\mathrm{P}_{\text {tot }} \\
\mathrm{mg} \mathrm{l}^{-1}\end{array}$ \\
\hline 2 & 16.86 & 8.10 & 789 & 999.0191 & 154 & 7.0 & & & & 70.4 & 10.4 & 0.01 & 0.024 & 0.006 \\
\hline 5 & 16.85 & 8.11 & 789 & 999.0209 & 155 & - & & & & 69.0 & 9.7 & 0.01 & 0.081 & 0.007 \\
\hline 10 & 16.85 & 8.12 & 790 & 999.0221 & 156 & 7.2 & 3.24 & 365.0 & 3.91 & 72.7 & 10.9 & 0.02 & 0.130 & 0.009 \\
\hline 30 & 16.60 & 7.95 & 795 & 999.0721 & 150 & 6.9 & 3.12 & 351.3 & 3.76 & 68.7 & 9.4 & 0.01 & 0.101 & 0.008 \\
\hline 35 & 16.04 & 7.46 & 810 & 999.1583 & 127 & 6.4 & - & - & - & 71.0 & 11.1 & 0.02 & 0.080 & 0.009 \\
\hline 40 & 15.54 & 7.33 & 813 & 999.2422 & 123 & 4.8 & 17.91 & 313.9 & 0.52 & 70.6 & 9.2 & 0.02 & 0.067 & 0.005 \\
\hline 60 & 15.26 & 7.19 & 820 & 999.2814 & 119 & 3.0 & 21.24 & 308.2 & 0.42 & 70.0 & 9.2 & $<0.01$ & 0.029 & 0.008 \\
\hline 80 & 15.18 & 7.25 & 814 & 999.2941 & 125 & 3.2 & 24.15 & 349.8 & 0.48 & 69.1 & 9.4 & 0.04 & 0.053 & 0.007 \\
\hline 100 & 15.15 & 7.20 & 813 & 999.2983 & 124 & 2.2 & 26.91 & 330.2 & 0.38 & 70.9 & 10.0 & $<0.01$ & 0.102 & 0.015 \\
\hline 120 & 15.15 & 7.18 & 811 & 999.2989 & 125 & - & 24.72 & 296.7 & 0.33 & 69.4 & 9.2 & 0.62 & 0.045 & 0.019 \\
\hline 130 & 15.15 & 7.17 & 813 & 999.2987 & 125 & - & - & - & - & 71.1 & 9.8 & $<0.01$ & 0.014 & 0.006 \\
\hline 140 & 15.15 & 7.17 & 813 & 999.2986 & 125 & 2.1 & 27.81 & 318.7 & 0.34 & 71.0 & 10.8 & $<0.01$ & 0.064 & 0.011 \\
\hline 142 & 15.15 & 7.16 & 813 & 999.2986 & 125 & 3.1 & - & - & - & 72.3 & 9.9 & 0.02 & 0.047 & 0.015 \\
\hline $\begin{array}{l}\text { Depth } \\
\mathrm{m}\end{array}$ & $\begin{array}{l}\mathrm{Na}_{\text {tot }} \\
\mathrm{mg} \mathrm{l}^{-1}\end{array}$ & $\begin{array}{l}\mathrm{K}_{\text {tot }} \\
\mathrm{mg}^{-1}\end{array}$ & $\begin{array}{l}\mathrm{Ca}_{\text {tot }} \\
\mathrm{mg} \mathrm{l}^{-1}\end{array}$ & $\begin{array}{l}\mathrm{Mg}_{\text {tot }} \\
\mathrm{mg} \mathrm{l}^{-1}\end{array}$ & $\begin{array}{l}\mathrm{Li}_{\text {sol. }} \\
\mathrm{mg} \mathrm{l}^{-1}\end{array}$ & $\begin{array}{l}\mathrm{Fe}_{\text {tot }} \\
\mathrm{mg} \mathrm{l}^{-1}\end{array}$ & $\begin{array}{l}\mathrm{Mn}_{\text {tot }} \\
\mathrm{mg}^{-1}\end{array}$ & $\begin{array}{l}\mathrm{Al}_{\text {tot }} \\
\mathrm{mg} \mathrm{l}^{-1}\end{array}$ & $\begin{array}{l}\mathrm{B}_{\text {tot }} \\
\mathrm{mg} \mathrm{l}^{-1}\end{array}$ & $\begin{array}{l}\mathrm{Si}_{\text {tot }} \\
\mathrm{mg} \mathrm{l}^{-1}\end{array}$ & $\begin{array}{l}\mathrm{As}_{\mathrm{tot}} \\
\mathrm{mg} \mathrm{l}^{-1}\end{array}$ & & & \\
\hline 2 & 63.1 & 5.7 & 39.9 & 29.6 & 0.10 & 0.004 & 0.017 & 0.004 & 4.4 & 14.1 & 0.007 & & & \\
\hline 5 & 61.7 & 5.7 & 41.4 & 29.7 & 0.10 & 0.004 & 0.016 & 0.006 & 3.8 & 14.7 & 0.008 & & & \\
\hline 10 & 62.6 & 5.7 & 39.7 & 30.2 & 0.10 & 0.004 & 0.012 & 0.004 & 4.0 & 16.0 & 0.005 & & & \\
\hline 30 & 63.9 & 5.6 & 40.6 & 29.1 & 0.10 & 0.003 & 0.003 & 0.004 & 4.5 & 17.0 & 0.006 & & & \\
\hline 35 & 62.2 & 5.6 & 40.9 & 29.4 & 0.09 & 0.005 & 0.009 & 0.003 & 4.1 & 18.4 & 0.006 & & & \\
\hline 40 & 65.5 & 5.5 & 43.0 & 29.7 & 0.09 & 0.004 & 0.002 & 0.004 & 3.9 & 19.1 & 0.006 & & & \\
\hline 60 & 63.9 & 5.7 & 44.4 & 28.6 & 0.11 & 0.024 & 0.004 & 0.004 & 3.5 & 20.8 & 0.005 & & & \\
\hline 80 & 63.5 & 5.7 & 42.2 & 29.5 & 0.10 & 0.008 & 0.002 & 0.002 & 3.7 & 20.8 & 0.005 & & & \\
\hline 100 & 64.0 & 5.5 & 42.8 & 29.5 & 0.10 & 0.010 & 0.008 & 0.003 & 4.1 & 18.1 & 0.004 & & & \\
\hline 120 & 63.3 & 5.5 & 42.4 & 29.3 & 0.10 & 0.026 & 0.041 & 0.007 & 3.6 & 18.0 & 0.004 & & & \\
\hline 130 & 62.4 & 5.8 & 40.1 & 28.9 & 0.10 & 0.005 & 0.001 & 0.004 & 2.9 & 22.2 & 0.005 & & & \\
\hline 140 & 63.6 & 5.6 & 42.7 & 28.1 & 0.10 & 0.037 & 0.035 & 0.002 & 3.2 & 21.8 & 0.005 & & & \\
\hline 142 & 63.0 & 5.7 & 42.7 & 31.2 & 0.10 & 0.010 & 0.003 & 0.003 & 2.5 & & 0.004 & & & \\
\hline
\end{tabular}

Table 1b.Vertical water physical and chemical parameters of Lake Cuicocha, $78 \mathrm{~m}$ basin, 18 March 2005.

\begin{tabular}{|c|c|c|c|c|c|c|c|c|c|c|c|c|c|c|}
\hline Depth & $\begin{array}{l}\text { Temp. } \\
{ }^{\circ} \mathrm{C}\end{array}$ & $\mathrm{pH}$ & $\begin{array}{l}\text { Cond } \\
{\left[25^{\circ} \mathrm{C}\right]} \\
\mu \mathrm{S} \mathrm{cm}^{-1}\end{array}$ & $\begin{array}{l}\text { Density } \\
\rho_{(S, T, P o)} \\
\mathrm{kg} \mathrm{m}^{-3}\end{array}$ & $\mathrm{mV}$ & $\begin{array}{l}\mathrm{O}_{2} \\
{\mathrm{mg} 1^{-1}}^{-1}\end{array}$ & $\begin{array}{l}\mathrm{CO}_{2} \\
\mathrm{mgl}^{-1}\end{array}$ & $\begin{array}{l}\mathrm{HCO}^{3+} \\
\mathrm{mgl}^{-1}\end{array}$ & $\begin{array}{l}\mathrm{CO}_{3}^{2-} \\
\mathrm{mg} \mathrm{l}^{-1}\end{array}$ & $\begin{array}{l}\mathrm{Cl}^{-} \\
\mathrm{mg} \mathrm{l}^{-1}\end{array}$ & $\begin{array}{l}\mathrm{SO}_{4}{ }^{2-} \\
\mathrm{mg} 1^{-1}\end{array}$ & $\begin{array}{l}\mathrm{NH}_{4}-\mathrm{N} \\
\mathrm{mg}^{-1}\end{array}$ & $\begin{array}{l}\mathrm{N}_{\text {tot }} \\
\mathrm{mgl}^{-1}\end{array}$ & 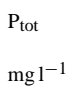 \\
\hline 5 & 16.87 & 8.15 & 789 & 999.0188 & 151 & 7.2 & & & & 71.7 & 10.7 & 0.03 & 0.091 & 0.005 \\
\hline 10 & 16.86 & 8.16 & 789 & 999.0202 & 153 & & 3.18 & 351.3 & 3.62 & 72.4 & 10.9 & 0.04 & 0.092 & 0.011 \\
\hline 30 & 16.53 & 7.72 & 800 & 999.0754 & 135 & 7.1 & & - & - & 71.3 & 11.4 & 0.02 & 0.099 & 0.010 \\
\hline 60 & 15.28 & 7.11 & 823 & 999.2792 & 108 & 2.7 & 36.28 & 269.9 & 0.18 & 74.6 & 10.8 & 0.04 & 0.061 & 0.007 \\
\hline 70 & 15.31 & 6.95 & 838 & 999.2736 & 101 & 2.1 & & & & 74.1 & 10.9 & 0.07 & 0.052 & 0.010 \\
\hline 74 & 15.31 & 6.93 & 840 & 999.2731 & 100 & 1.2 & & & & 70.9 & 9.0 & 0.08 & 0.125 & 0.014 \\
\hline $\begin{array}{l}\text { Depth } \\
\mathrm{m}\end{array}$ & $\begin{array}{l}\mathrm{Na}_{\text {tot }} \\
\mathrm{mg}^{-1}\end{array}$ & $\begin{array}{l}\mathrm{K}_{\mathrm{tot}} \\
{\mathrm{mg} 1^{-1}}^{-1}\end{array}$ & $\begin{array}{l}\mathrm{Ca}_{\text {tot }} \\
\mathrm{mg}^{-1}\end{array}$ & $\begin{array}{l}\mathrm{Mg}_{\text {tot }} \\
\mathrm{mg}^{-1}\end{array}$ & $\begin{array}{l}\mathrm{Li}_{\text {sol. }} \\
\mathrm{mg} \mathrm{1}^{-1}\end{array}$ & $\begin{array}{l}\mathrm{Fe}_{\text {tot }} \\
\mathrm{mg}^{-1}\end{array}$ & $\begin{array}{l}\mathrm{Mn}_{\text {tot }} \\
\mathrm{mg} \mathrm{l}^{-1}\end{array}$ & $\begin{array}{l}\mathrm{Al}_{\text {tot }} \\
{\mathrm{mg} 1^{-1}}^{-1}\end{array}$ & $\begin{array}{l}\mathrm{B}_{\mathrm{tot}} \\
\mathrm{mg} \mathrm{l}^{-1}\end{array}$ & $\begin{array}{l}\mathrm{Si}_{\text {tot }} \\
\mathrm{mg} \mathrm{l}^{-1}\end{array}$ & $\begin{array}{l}\text { As }_{\text {tot }} \\
\mathrm{mg}^{-1}\end{array}$ & & & \\
\hline 30 & 63.0 & 5.6 & 43.0 & 30.8 & 0.11 & 0.004 & 0.002 & 0.008 & 4.6 & 19.3 & 0.007 & & & \\
\hline 35 & 62.8 & 5.8 & 44.1 & 30.8 & 0.12 & 0.004 & 0.001 & 0.004 & 4.0 & 20.1 & 0.004 & & & \\
\hline 40 & 62.2 & 5.6 & 45.6 & 31.3 & 0.11 & 0.006 & 0.002 & 0.003 & 4.4 & 20.4 & 0.008 & & & \\
\hline 60 & 62.9 & 5.7 & 47.1 & 31.8 & 0.11 & 0.030 & 0.007 & 0.003 & 4.1 & 19.9 & 0.004 & & & \\
\hline 70 & 63.0 & 5.7 & 48.1 & 31.7 & 0.11 & 0.080 & 0.019 & 0.003 & 4.6 & 19.9 & 0.004 & & & \\
\hline 75 & 63.9 & 5.8 & 49.1 & 32.2 & 0.11 & 0.179 & - & 0.004 & 4.6 & 19.9 & 0.004 & & & \\
\hline
\end{tabular}

located southeast of the crater lake (Fig. 6). The monomictic circulation behaviour of the lake was confirmed by a corresponding change of $\mathrm{pH}$ and $\mathrm{CO}_{2}$ (see Figs. 11 and 12).

The temperature of the total water body of Lake Cuicocha had the tendency to increased values since the beginning of data acquisition in August 2003 by about $0.1^{\circ} \mathrm{C}$ per year. This hypolimnic temperature increase (April 2004April 2006) corresponds to a mean hypolimnic heat flow $\theta_{w}=+0.005 \mathrm{~W} \mathrm{~m}^{-2}$, while for the total lake the heat flow was calculated to $\theta_{w}=+0.012 \mathrm{~W} \mathrm{~m}^{-2}$. Nevertheless the heat balance of the lake was determined by lake mixing (overturn) and nocturnal surface cooling, and the heat content changed from 31 March 2004 to 1 September 2004 for $\theta_{w}=-0.124 \mathrm{~W} \mathrm{~m}^{-2}$; thus the hypolimnic temperature increase in Lake Cuicocha cannot be used as an indicator of volcanic activity. 
Table 2. Water chemistry (in $\mathrm{mg} \mathrm{L}^{-1}$ ) of Lake Cuicocha $\left(78 \mathrm{~m}\right.$ and $148 \mathrm{~m}$ basin; $\mathrm{WS}_{1}$, respectively $\mathrm{WS}_{2}$, Fig. 4) and its water inflow (cascade $\mathrm{C}_{2}$ ), the hydrothermal water inflow in Island Yerovi (WWS), and Lake Mojanda (central profile in the lake), mean of 2003-2005, Mojanda mean of 2003. sd $=$ standard diviation, *) $n=2$.

\begin{tabular}{|c|c|c|c|c|c|c|c|c|c|c|}
\hline \multirow[t]{2}{*}{ Parameter } & \multicolumn{2}{|c|}{$\begin{array}{l}\text { Lake Cuicocha } \\
148 \mathrm{~m} \text { basin }\end{array}$} & \multicolumn{2}{|c|}{$\begin{array}{l}\text { Lake Cuicocha } \\
78 \mathrm{~m} \text { basin }\end{array}$} & \multicolumn{2}{|c|}{$\begin{array}{l}\text { Water inflow } \\
\text { (cascades) }\end{array}$} & \multicolumn{2}{|c|}{$\begin{array}{l}\text { Hydrothermal water } \\
\text { Island Yerovi }\end{array}$} & \multicolumn{2}{|c|}{ Lake Mojanda } \\
\hline & $\begin{array}{c}\text { mean } \\
(n=38)\end{array}$ & sd & $\begin{array}{l}\text { mean } \\
(n=17)\end{array}$ & sd & $\begin{array}{l}\text { Mean } \\
(n=5)\end{array}$ & sd & $\begin{array}{c}\text { mean } \\
(n=11)\end{array}$ & sd & $\begin{array}{l}\text { mean } \\
(n=9)\end{array}$ & sd \\
\hline $\mathrm{Na}_{\text {total }}$ & 61.7 & 5.2 & 61.7 & 1.9 & 10.2 & 1.9 & 247 & 11.9 & 1.6 & 0.3 \\
\hline $\mathrm{Ca}_{\text {total }}$ & 47.4 & 10.0 & 43.5 & 2.6 & 18.5 & 19.7 & 120 & 13.0 & 2.6 & 0.3 \\
\hline $\mathrm{K}_{\text {total }}$ & 5.4 & 0.5 & 5.7 & 0.1 & 1.3 & 0.3 & 14.4 & 1.1 & 0.66 & 0.13 \\
\hline $\mathrm{Li}_{\text {total }}$ & 0.113 & 0.011 & 0.112 & 0.014 & 0.017 & 0.008 & 0.330 & 0.007 & 0.001 & 0.001 \\
\hline $\mathrm{Mg}_{\text {total }}$ & 32.0 & 5.6 & 30.5 & 1.1 & 4.0 & 1.2 & 70.2 & 1.2 & 3.2 & 0.31 \\
\hline $\mathrm{Fe}_{\text {total }}$ & 0.028 & 0.080 & 0.025 & 0.045 & 0.144 & 0.011 & 7.4 & 4.6 & 0.025 & 0.026 \\
\hline $\mathrm{Mn}_{\text {total }}$ & 0.021 & 0.050 & 0.006 & 0.008 & 0.010 & 0.007 & 0.220 & 0.025 & 0.002 & 0.005 \\
\hline $\mathrm{Al}_{\text {total }}$ & 0.021 & 0.035 & 0.006 & 0.003 & 0.250 & 0.092 & 0.164 & 0.23 & 0.100 & 0.048 \\
\hline $\mathrm{B}^{3+}$ & 4.3 & 0.8 & 4.1 & 0.6 & 0.03 & 0.07 & 5.6 & 1.4 & 0.68 & 0.23 \\
\hline $\mathrm{HCO}_{3}^{-}$ & 240.4 & 89.3 & 341 & 28.9 & $\left(69.1^{*}\right)$ & & 420 & & 26.4 & 6.8 \\
\hline $\mathrm{Si}_{\text {total }}$ & 20.6 & 2.0 & 21.1 & 0.2 & 25.3 & 4.8 & 51.6 & 2.5 & 4.52 & 0,56 \\
\hline $\mathrm{As}_{\text {total }}$ & 0.003 & 0.001 & 0.006 & 0.002 & 0.003 & 0.001 & 0.243 & 0.259 & 0.001 & 0.002 \\
\hline $\mathrm{Cl}^{-}$ & 69.4 & 2.4 & 72.0 & 1.7 & 3.2 & 1.8 & 171 & 2.6 & 0.15 & 0.15 \\
\hline $\mathrm{SO}_{4}^{2-}$ & 13.8 & 3.1 & 12.5 & 2.3 & 9.7 & 4.6 & 193 & 14.6 & 1.5 & 0.07 \\
\hline$P_{\text {total }}^{4}$ & 0.015 & 0.017 & 0.017 & 0.011 & 0.15 & 0.06 & 0.21 & 0.02 & 0.011 & 0.006 \\
\hline
\end{tabular}

\subsection{Warm water spring inflow}

Temperature profiles point out an increase in conductivity and temperature in the $78 \mathrm{~m}$ lake basin a few meters above the lake floor, indicating a warm water inflow; in the $148 \mathrm{~m}$ lake basin, no increased temperature and conductivity in the sediment overlying water were observed (Fig. 5). But in the $78 \mathrm{~m}$ lake basin the differences in temperature and conductivity were small, about $+0.03^{\circ} \mathrm{C}$ and $+17 \mu \mathrm{S} \mathrm{cm}^{-1}$ between 60 and $74 \mathrm{~m}$ (Table 1b). The significance of this warm water inflow in $78 \mathrm{~m}$ could be verified by horizontal monitoring near the sediment with the lake profiler in both lake basins, resulting in a positive temperature - conductivity correlation (Fig. 7), being characteristic for warm water interference. The density of this water amounted $\rho=999.3921-999.3981$, that means the density was a little bit increased to lake water (Table 1b) and it could accumulate at the lake bottom, but uprising of gas bubbles and the formation of billows led to a good mixing. In the $148 \mathrm{~m}$ basin such a temperature - conductivity correlation did not exist and water near the sediment was quite homogenous in conductivity and temperature.

Close to Island Yerovi, an outlet of rising warm water (mean temperature of $24.5^{\circ} \mathrm{C}, \mathrm{sd}=1.1^{\circ} \mathrm{C}$; mean conductivity $=2879 \mu \mathrm{S} \mathrm{cm}^{-1}, \mathrm{sd}=859 \mu \mathrm{S} \mathrm{cm}^{-1}$ ) enters into the lake. The warm water temperature was about $8^{\circ} \mathrm{C}$ above epilimnic lake water and above the air temperature (July as hottest month: $10.5-24.1^{\circ} \mathrm{C}$ as mean min/max night/day temperature, December as coldest month: $8.1-15.4^{\circ} \mathrm{C}$ as mean min/max night/day temperature). The water is rich in sodium, calcium and magnesium as cations and chloride, sulphate, bicarbonate and silicate as anions (Table 2), density of the water is $\rho=$ 997.9261, that means after inflow into the lake an overflow occured.

\subsection{Water chemistry}

Lake Cuicocha is a sodium bicarbonate lake (mean concentration $62 \mathrm{mg} \mathrm{L}^{-1} \mathrm{Na}^{+}, 240 \mathrm{mg} \mathrm{L}^{-1} \mathrm{HCO}_{3}^{-}$) with significant amounts of magnesium and calcium $\left(32 \mathrm{mg} \mathrm{L}^{-1} \mathrm{Mg}^{2+}\right.$, $\left.47 \mathrm{mg} \mathrm{L}^{-1} \mathrm{Ca}^{2+}\right)$ as cations and chloride $\left(69 \mathrm{mg} \mathrm{L}^{-1} \mathrm{Cl}^{-}\right)$ as an anion (Table 2). Ions of minor concentration are the cations $\mathrm{K}^{+}, \mathrm{Li}^{+}, \mathrm{Fe}^{2+}, \mathrm{Mn}^{2+}, \mathrm{Al}^{3+}$ and the anions $\mathrm{SO}_{4}^{2-}, \mathrm{SiO}_{3}^{2-}, \mathrm{BO}_{3}^{3-}$, and $\mathrm{PO}_{4}^{3-}$. In relation to non-volcanic waters, the concentration of $\mathrm{Si}$ must be classified as very high ( $\left.21 \mathrm{mg} \mathrm{L}^{-1} \mathrm{Si}\right)$.

The dissolved ionic concentration of Lake Cuicocha is significantly elevated with a conductivity value of about $800 \mu \mathrm{S} \mathrm{cm}^{-1}$, compared with the inflow from cascades $\left(260 \mu \mathrm{S} \mathrm{cm}^{-1}\right)$ and the non active caldera Lake Mojanda $\left(35 \mu \mathrm{S} \mathrm{cm}^{-1}\right)$. Ionic concentrations indicate a significant influence of the warm water springs for the water balance. The geochemical mass balances of Lake Cuicocha (Cuicocha lake water, Lake Mojanda water as rainwater filled caldera, and warm water spring at Yerovi; Table 2) give a portion of warm and ionic rich water of $34 \%$ (based on potassium balance), of $24 \%$ (sodium balance), respectively of $34 \%$ (lithium balance).

The water chemistry of Lake Cuicocha (78 m, $148 \mathrm{~m}$ ), the cascades and of Lake Mojanda do not differ significantly in terms of relative $\mathrm{Cl}^{-}-\mathrm{SO}_{4}^{2-}-\mathrm{HCO}_{3}^{-}$-content (Fig. 8a), the waters are bicarbonate water. The warm water spring possesses a higher sulphate content. The relative cation content (KMg-Na-diagram, Fig. 8b) shows quite similar ionic composition for Lake Cuicocha, the cascades, the warm water inflow (sodium dominated water), while Lake Mojanda has magnesium rich water. The $\mathrm{NH}_{4}$-Li-B-digram (Fig. 8c) shows a high significance of boron in Lake Cuicocha and in the warm water spring; migration of boron is mainly associated 

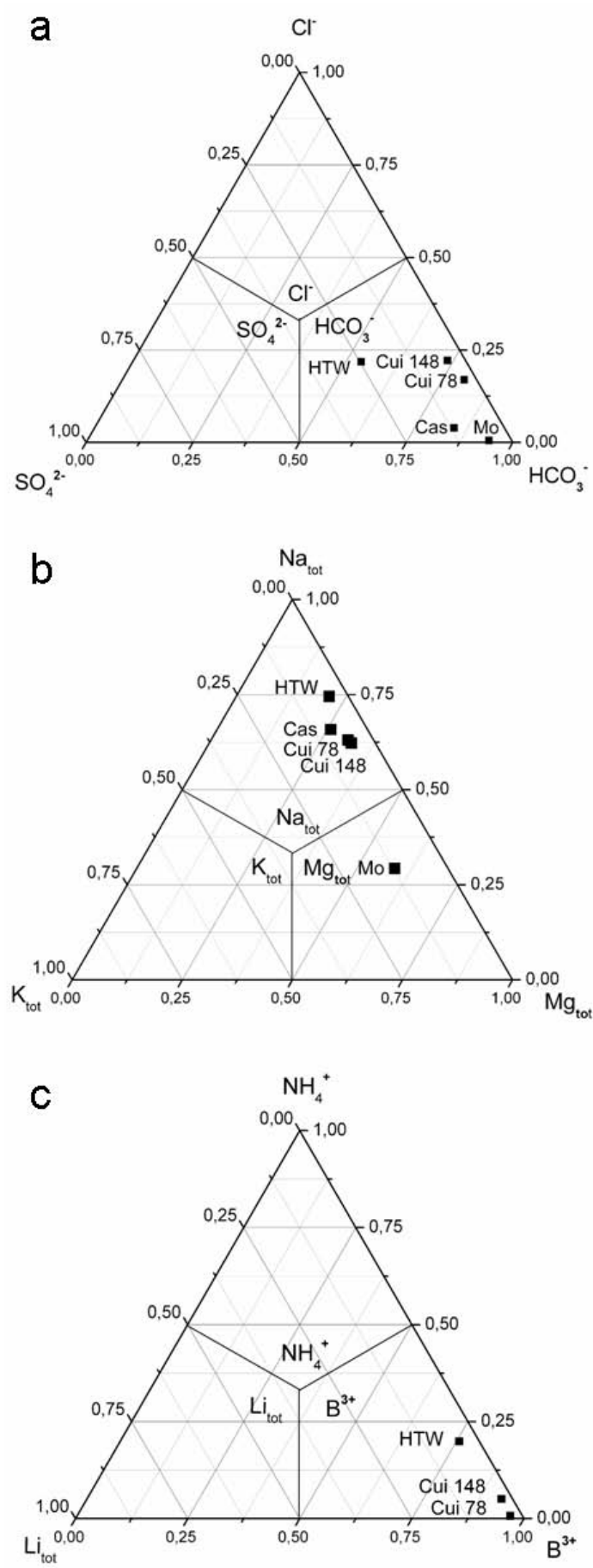

Fig. 8. Diagram $\mathrm{HCO}_{3}^{-}-\mathrm{Cl}^{-}-\mathrm{SO}_{4}^{2-}(8 \mathbf{a}), \mathrm{Na}-\mathrm{K}-\mathrm{Mg}(8 \mathbf{b})$ and $\mathrm{B}^{3+}$ $\mathrm{NH}_{4}^{+}$-Li (8c) for the samples of Lake Cuicocha (Cui, $78 \mathrm{~m}$ and $138 \mathrm{~m}$ basin), warm water inflow (HTW), cascade water inflow (Cas), Mojanda (Mo) and Lake Quilotoa (Quil).

to vapour phase which requires a high temperature, negligible concentrations of $\mathrm{Li}$ indicate to insignificant leaching of rocks (Martini et al., 1994).

The vertical profiles during thermal stratification period
(Fig. 6) show an epilimnion, which stretches down to $35 \mathrm{~m}$. In the 148 basin chemical composition of the epilimnic water and of the hypolimnic water does not differ very much, due to the weak thermal stratification $\left(\Delta \mathrm{T}=1.7^{\circ} \mathrm{C}\right)$ and to the partial mixing processes by night cooling, the so called atelomixis (Gunkel and Beulker, 2008).

In the $78 \mathrm{~m}$ basin, the epilimnic water does not differ significantly from the $148 \mathrm{~m}$ basin, due to strong wind induced horizontal water currents. But the water samples near the lake bottom show clearly the inflow of warm water springs with increased temperature $\left(\Delta \mathrm{T}=0.03^{\circ} \mathrm{C}\right.$, compared with the $148 \mathrm{~m}$ basin) and conductivity $\left(\Delta\right.$ Cond. $\left.=26 \mu \mathrm{S} \mathrm{cm}^{-1}\right)$ as well as reduced $\mathrm{pH}(\Delta \mathrm{pH}=0.4)$ and $\mathrm{E}_{7}(\Delta 18 \mathrm{mV})$. The input of warm water is too confirmed by the concentration gradient near the lake floor of some water chemical parameters $\left(\mathrm{O}_{2}, \mathrm{Ca}, \mathrm{Mg}, \mathrm{Fe}\right)$. But this inflow water does not build up a chemocline, a consequence of mixing by uprising gas bubbles (see below).

In Lake Cuicocha $\mathrm{Al}^{3+}$ concentration is elevated (up to $0.14 \mathrm{mg} \mathrm{L}^{-1} \mathrm{Al}^{3+}$ ), but still within the range of surface waters. Soluble $\mathrm{Al}$ from weathered andesitic rocks covering the catchment area is washed out and transported into the lake by subsurface runoff. After input into the lake, polymerisation reactions occur, forming gelatinous $\mathrm{Al}_{13}$ polynuclear cations aging to microcrystals (Gunkel et al., 2009a).

The concentration of boron is increased in the lake and amounts to about $4.3 \mathrm{mg} \mathrm{L}^{-1}$ (= mean, max. $=6.2 \mathrm{mg} \mathrm{L}^{-1}$ ). Whereas the incoming waters (cascades, rain) supply boron in only negligible concentrations (Table 2), elevated amounts were found in the warm water emission at Island Yerovi. It must be assumed that boron is entering the lake water by dissolution of volcanic gases into warm water below the lake bottom or by steam leakage from a high enthalpy geothermal reservoir.

\section{5 $\mathrm{CO}_{2}$ emissions}

Continuous gas emissions in Lake Cuicocha occur at four positions, two sites near the shore at a depth of up to $2 \mathrm{~m}$, in the channel between the islands at 5-10 $\mathrm{m}$ depth (a new emission area detected in 2006), and in the western basin of the lake at a depth of $78 \mathrm{~m}$ (see Fig. 4). The emission of gases from the bottom of the lake was verified by using sonar and divers (Fig. 9).

Underwater gas bubble analyses near Island Yerovi show the main components to be $\mathrm{CO}_{2}$ with $51.1 \%(\mathrm{sd}=10.1 ; n=16)$ and $\mathrm{N}_{2}$ with $23.1 \%(\mathrm{sd}=3.5)$ and with small amounts of $\mathrm{O}_{2}(3.04 \%, \mathrm{sd}=1.64), \mathrm{CH}_{4}(1.66 \%, \mathrm{sd}=0.72)$ and $\mathrm{CO}(0.32 \%$, $\mathrm{sd}=0.18)$. Gas emission at the north-west shore show a similar composition.

In Lake Cuicocha, increased concentrations of $\mathrm{CO}_{2}$ were registered with a $\mathrm{CO}_{2}$ concentration of about $35 \mathrm{mg} \mathrm{L}^{-1}$ $\left(=27 \mathrm{mLCO}_{2}\right.$ per litre water at local surface pressure). The highest concentrations occurred in the deep water $>100 \mathrm{~m}$ (Fig. 10), a consequence of the carbonic acid equilibrium 


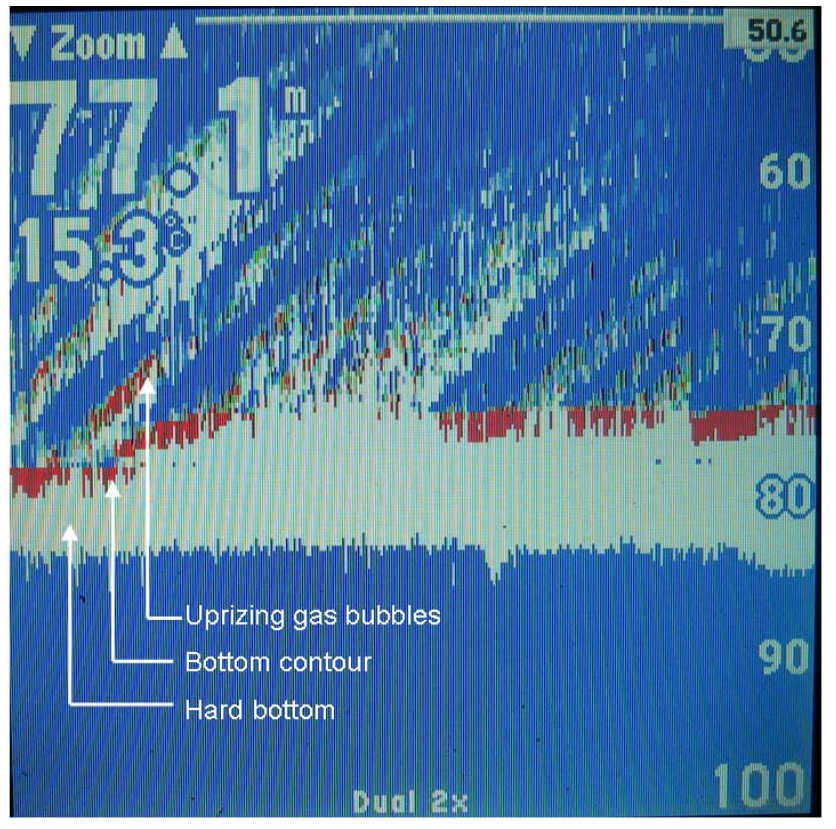

Fig. 9. Sonar print of a gas release at the floor of Cuicocha, western basin, $78 \mathrm{~m}$ depth, picture frequency is 0.3 per minutes; red is the return signal, from the hard bottom (red horizontal line) and a few gas bubbles (increasing line), the white line under the bottom contour indicates a hard bottom (whiteline function).

and the decreasing $\mathrm{pH}$ in the hypolimnic water; the hydrogen carbonate concentration was much higher than the $\mathrm{CO}_{2}$ concentration and amounted $320 \mathrm{mg} \mathrm{L}^{-1}$ (Table 1a). In the $78 \mathrm{~m}$ basin, where the $\mathrm{CO}_{2}$ emission took place, were registered slightly higher $\mathrm{CO}_{2}$ concentrations in the hypolimnion than in the $148 \mathrm{~m}$ basin. Nevertheless, in situ $\mathrm{CO}_{2}$ saturation is low, corresponding to $0.2 \%$ saturation level based on gas input. Therefore spontaneous degassing can be excluded.

In the epilimnion and metalimnion $(<50 \mathrm{~m}$ water depth) reduced $\mathrm{CO}_{2}$ saturation concentrations occurred due to water heating and $\mathrm{pH}$ increase by primary production (Fig. 11). Only directly near the water surface a slightly increased $\mathrm{CO}_{2}$ concentrations up to $23 \mathrm{mg} \mathrm{L}^{-1}$ were also registered with an oversaturation level of up to 46 times, related to partial pressure of $\mathrm{CO}_{2}$ at the lake surface. These changes of the $\mathrm{CO}_{2}$ concentration were given by the carbonic acid equilibrium and the high portion of bicarbonate in the water, and the sum of the $\mathrm{CO}_{2}$ species $\left(\mathrm{CO}_{2}, \mathrm{HCO}_{3}^{-}\right.$, $\mathrm{CO}_{3}^{2-}$ ) was equal in the upper water body $(0-50 \mathrm{~m})$ with $354.2 \mathrm{mg} \mathrm{L}^{-1}\left(\mathrm{sd}=15.8 \mathrm{mg} \mathrm{L}^{-1}\right)$ and in water depths $>50 \mathrm{~m}$ to $346.4 \mathrm{mg} \mathrm{L}^{-1}$ ( $\mathrm{sd}=25.1$ ).

The accumulated $\mathrm{CO}_{2}$ in the hypolimnic water is reduced during the lake's overturn period from June to August, and an emission of $\mathrm{CO}_{2}$ to the atmosphere occurs (Fig. 12). This monomictic circulation behaviour of the lake prevents an increase in $\mathrm{CO}_{2}$ to dangerous concentration levels.

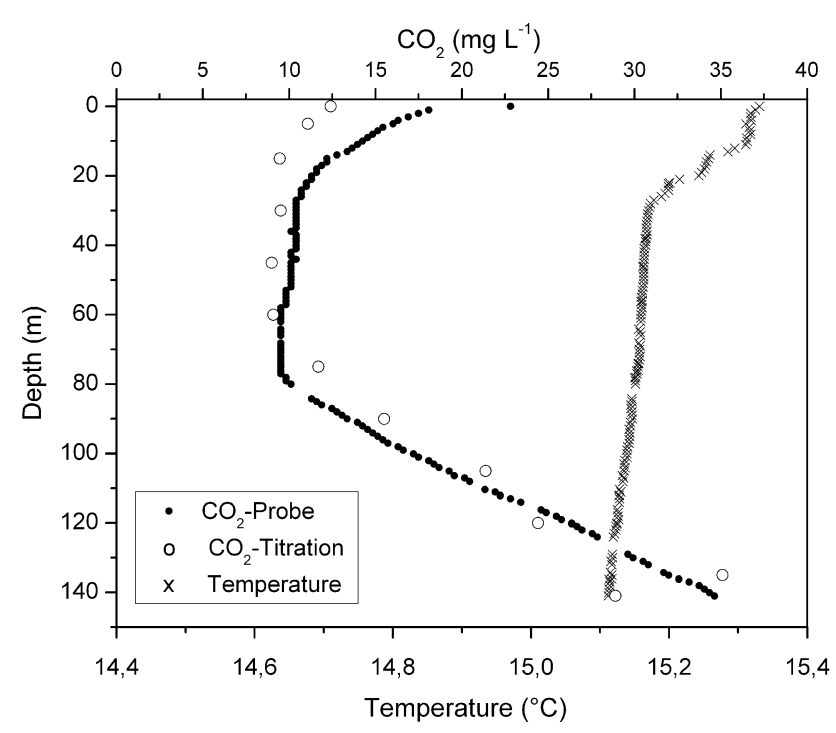

Fig. 10. $\mathrm{CO}_{2}$ concentrations in Lake Cuicocha by lake profiler and $\mathrm{pK}_{\mathrm{a}} / \mathrm{pK}_{\mathrm{b}}$ determination; the in situ saturation calculated to pure $\mathrm{CO}_{2}$ is $0.08-0.10 \%$.

\section{6 $\mathrm{CO}_{2}$ and the carbonic acid equilibrium}

Precipitation of calcium carbonate was registered at the shoreline of Lake Cuicocha leading to $\mathrm{CaCO}_{3}$ crusts (calcite) of about $1 \mathrm{~cm}$ thickness, reaching down deep into the epilimnion. These precipitations are caused mainly by epibiontic diatoms and blue green algae, which establish a microenvironment. The intensive photosynthetic production (with mean $\mathrm{O}_{2}$ oversaturation of $199 \% 5 \mathrm{~mm}$ inside the $\mathrm{CaCO}_{3}$ crusts, $\min .=152 \%$, max. $=216 \%, n=13$ ) leads to an increase in $\mathrm{pH}$ and favours carbonate precipitation. In this way, $\mathrm{CaCO}_{3}$ is continuously precipitated, but wave action partly destroys these crusts, forming fine carbonate debris, which sinks down to the lake bottom.

In deeper water $(>40 \mathrm{~m})$ carbonate re-dissolution conditions exist (Fig. 13) and the Ca-carbonate precipitates will be dissolved. The Ca-carbonate saturation index is strongly correlated to $\mathrm{pH}$ and temperature and inversely correlated to conductivity, these parameters change characteristic within the epilimnic/hypolimnic zone. This leads to a cycling of $\mathrm{Ca}^{2+}$ and $\mathrm{CO}_{3}^{2-} / \mathrm{HCO}_{3}^{-} / \mathrm{CO}_{2}$, in the epilimnion $\mathrm{CO}_{3}^{2-} / \mathrm{HCO}_{3}^{-} / \mathrm{CO}_{2}$ is reduced due to precipitation, and in the hypolimnion $\mathrm{CO}_{3}^{2-} / \mathrm{HCO}_{3}^{-} / \mathrm{CO}_{2}$ is increased due to dissolution of the carbonate debris (Fig. 14). This re-dissolution of carbonate in connection with decreased $\mathrm{pH}$ must be regarded as another source of $\mathrm{CO}_{2}$ in the hypolimnic water.

\subsection{Lake colmation}

The sediments in Lake Cuicocha form a thin layer of up to $10 \mathrm{~cm}$, which covers the stony lake bottom (with stones of about $20 \mathrm{~cm} \varnothing$ ). The sediment was covered by a thin 


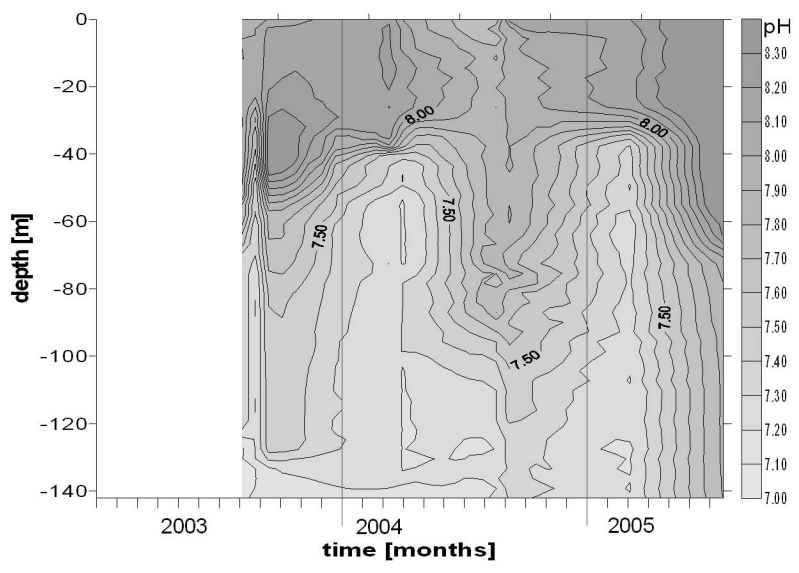

Fig. 11. $\mathrm{pH}$ isopleths of Lake Cuicocha, $148 \mathrm{~m}$ position.

oxic layer, consisting of brown flocs of up to $0.5 \mathrm{~cm}$ diameter $\left(E_{7}=200 \mathrm{mV}\right.$ in $148 \mathrm{~m}$ depth), and below this a layer of fine anoxic material was registered. The anoxic sediment was formed by mineral and organic detritus (Table 3). Sediments from the lake bottom $(78 \mathrm{~m}, 148 \mathrm{~m})$ only contained traces of $\mathrm{CaCO}_{3}(10-20 \mathrm{~g} / \mathrm{kg} \mathrm{ds})$, due to $\mathrm{CaCO}_{3}$ redissolution, normally the main sediment building component in lakes. The upper oxic sediment layer is formed by precipitation of $\mathrm{Al}$ and $\mathrm{Si}$ in the water column, which leads to $\mathrm{Al}$ polymers, forming large aggregates $(50-500 \mu \mathrm{m})$ together with organic detritus, living algal cells, bacteria and mineral detritus. These flocs sink down, but are easily resuspended by uprising gas bubbles. Sediment traps, which were exposed to different water depths, showed high sedimentation rates and collected fresh material in the range of a few millimetres ( $15 \mathrm{~m}$ depth) up to $1 \mathrm{~cm}(75 \mathrm{~m}$ depth). The composition of the settled material revealed high concentrations of mineral detritus, pyrite, iron oxidizing bacteria and diatom frustules. The trapped material had a much higher $\mathrm{Fe}$ concentration than the lake sediment, a consequence of anoxic conditions in the lake sediment with $\mathrm{Fe}^{3+}$ reduction to soluble $\mathrm{Fe}^{2+}$ and of oxidising of $\mathrm{Fe}^{2+}$ in the lake water with formation of $\mathrm{FeO}(\mathrm{OH})$ precipitates.

The gas emissions and the inflow by warm water springs led to the formation of holes in the sediment, registered by the underwater camera (see Gunkel et al., 2008). Thus the lake colmation in the $78 \mathrm{~m}$ basin is destroyed, and this is promoted by the thin sediment layer due to calcium carbonate dissolution, the young age of the lake, and by the uprising of gas bubbles, which occur continuously with high intensity and lead to a re-suspension of the sediments.

\subsection{Water losses}

After an earthquake in 5 March 1987, a rapid water level decrease of about $2 \mathrm{~m}$ was observed within two weeks, probably caused by damage to the lake's colmation (per-

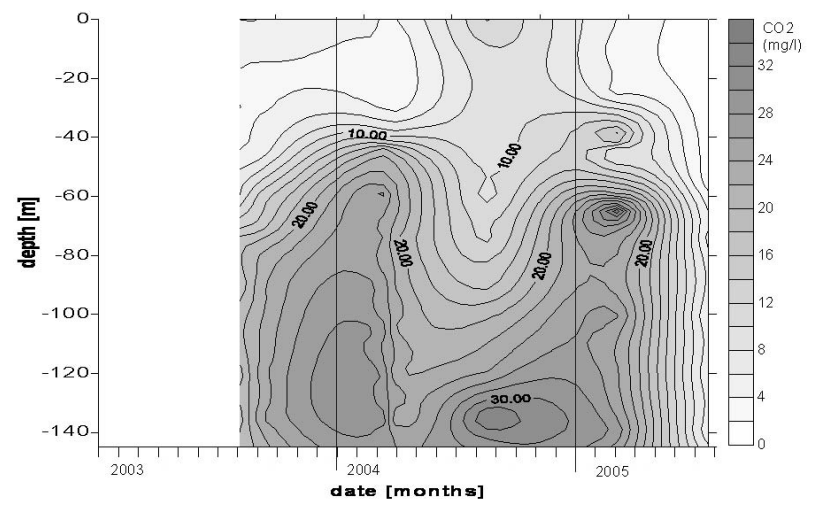

Fig. 12. Isopleths of $\mathrm{CO}_{2}$ concentrations in Lake Cuicocha, $148 \mathrm{~m}$ position.

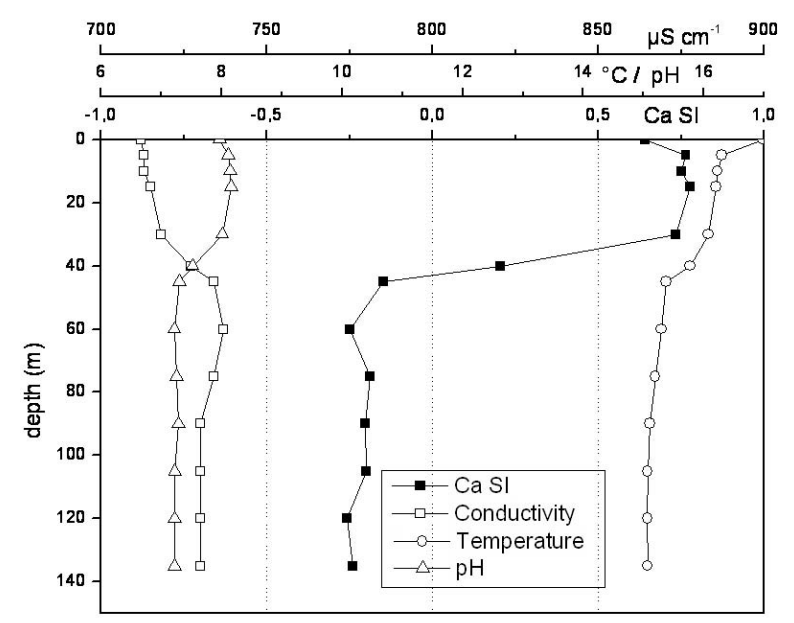

Fig. 13. Calcium carbonate solution index (MINEQL 4.5), temperature, $\mathrm{pH}$ and conductivity in Lake Cuicocha (25 March 2004).

sonal communications of the National Park guide, 2004). The earthquake with two seismic shocks occurred $60 \mathrm{~km}$ east of Cuicocha, in 3 and $12 \mathrm{~km}$ depth, with a magnitude Ms=6.9 (Espinosa et al., 1991). Today, the water level is decreasing continuously by about $300 \mathrm{~mm}$ per year, and up to now the total decrease in the water level amounts to $6 \mathrm{~m}$. This is obvious at the lake shoreline, where carbonate precipitations above the recent water level document former lake water levels. The water balance of the lake is determined by nearly similar precipitation and evaporation rates (2005: precipitation $=1294 \mathrm{~mm} / \mathrm{a}$, evaporation $=1460 \mathrm{~mm} / \mathrm{a}$ ), while the decrease of the water level was $390 \mathrm{~mm}$ (Fig. 15). A seasonal increase of the water level can be observed during the rainy period, but the input of surface water from the catchment area is not able to compensate for the permanent decrease in the water level. Already an inflow of 5\% of the yearly precipitation in the watershed (runoff coefficient of $\alpha=0.05$ ) corresponds to a $310 \mathrm{~mm}$ lake level rise. The two 
Table 3. Composition of settling material collected in sediment traps at the centre of the $78 \mathrm{~m}$ basin and of sediments (78 and $148 \mathrm{~m}$ depth) of Lake Cuicocha (ds = dry substance).

\begin{tabular}{llll}
\hline Parameter & $\begin{array}{l}\text { Settling material } \\
(n=3)\end{array}$ & $\begin{array}{l}\text { Sediment } 78 \mathrm{~m} \\
(n=1)\end{array}$ & $\begin{array}{l}\text { Sediment } 148 \mathrm{~m} \\
(n=2)\end{array}$ \\
\hline $\mathrm{Ca}\left(\mathrm{g} \mathrm{kg}^{-1} \mathrm{ds}\right)$ & 12.4 & 20.3 & 10.6 \\
$\mathrm{Fe}\left(\mathrm{g} \mathrm{kg}^{-1} \mathrm{ds}\right)$ & 73.6 & 9.9 & 12.7 \\
$\mathrm{Mg}\left(\mathrm{g} \mathrm{kg}^{-1} \mathrm{ds}\right)$ & 4.1 & 3.3 & 2.1 \\
$\mathrm{~K}\left(\mathrm{~g} \mathrm{~kg}^{-1} \mathrm{ds}\right)$ & 0.68 & 0.24 & 0.15 \\
$\mathrm{Mg}\left(\mathrm{g} \mathrm{kg}^{-1} \mathrm{ds}\right)$ & 4.1 & 3.3 & 2.1 \\
$\mathrm{P}\left(\mathrm{g} \mathrm{kg}^{-1} \mathrm{ds}\right)$ & & 46.1 & 24.1 \\
\hline
\end{tabular}

permanent cascade have a delivery of a few litre $\mathrm{s}^{-1}$, while the periodical cascade of the intermittent inflow river (Quebrada Chunabi) has a high delivery (a few $\mathrm{m}^{3} \mathrm{~s}^{-1}$ ) but water flow occurs very scarcely; an estimation of the inflow rate is not possible, because the water losses by percolation are unknown. The discharge of the nearby spring (delivery in the range of $1-21 \mathrm{~s}^{-1}$ ) corresponds only to a yearly water level decrease in Lake Cuicocha of $12 \mathrm{~mm}$. Thus a rough calculation of the water losses by percolation gives about $610 \mathrm{~mm}$ per year (rainwater run off and observed decrease of the water table).

Water level decrease is not caused by reduced rainfall due to climate change, because it does not take place at the nearby lakes Laguna Mojanda and Lago San Pablo. Thus, a significant amount of the lake's water is lost yearly by percolation.

\section{Discussion}

\subsection{Lake water use and health impact}

Water quality of Lake Cuicocha is characterised by an elevated concentration of ions, due to the inflow of warm water springs. The comparison with Lake Mojanda, a nearby inactive caldera lake, fed by rain water, confirms the different water qualities: Mojanda has a conductivity of about $35 \mu \mathrm{S} \mathrm{cm}^{-1}$, Lake Cuicocha of $800 \mu \mathrm{S} \mathrm{cm}^{-1}$. This elevated conductivity of Lake Cuicocha points at an inflow of ionic rich water such as warm water springs or hydrothermal water, confirmed by the geochemical mass balances of Lake Cuicocha with a portion of warm and ionic rich water of about $25-35 \%$ (potassium, sodium and lithium balance). The $\mathrm{Na} / \mathrm{Cl}$ as well as the $\mathrm{Cl} / \mathrm{SO}_{4}$ ratio does not give a mixing triangle, but some input of $\mathrm{HCl}$ and $\mathrm{SO}_{2}$ with volcanic gases must be taken into account.

Nowadays, Lake Cuicocha water is used directly as drinking water by some of the nearby population and the spring fed by the lake is used by many people for drinking and irrigation. Although Lake Cuicocha is an oligotrophic lake, it must be stated that the water does not reach drinking water quality. The main reason is the elevated concentration of boron $\left(4.2 \mathrm{mg} \mathrm{L}^{-1} \mathrm{~B}, \mathrm{sd}=0.7 \mathrm{mg} \mathrm{L}^{-1}, n=83\right.$, data from 2003 2005), which exceeds the WHO provisional guideline value of $0.5 \mathrm{mg} \mathrm{L}^{-1} \mathrm{~B}$ by nearly 10 -fold (WHO, 2004). Although boron is not a highly toxic water constituent for humans, permanent use of Lake Cuicocha water for drinking can impact on human health. The water can not be used for irrigation agriculture, because the boron concentration is acutely toxic to plants, for sensitive plants a limiting value of $0.5-$ $1.0 \mathrm{mg} \mathrm{L}^{-1} \mathrm{~B}$ is given, while tolerant plants are affected by $2.0-4.0 \mathrm{mg} \mathrm{L}^{-1} \mathrm{~B}$. Boron is known to be beneficial to plants as a micronutrient, but is toxic to plants at higher concentrations (Scheffer and Schachtschabel, 1989; Moss and Nagpal, 2003).

\subsection{Occurrence of underwater volcanic activities}

In Lake Cuicocha, emission of gases can be registered at several areas by the application of sonar and the use of divers. The composition of the gases, with high concentrations of $\mathrm{CO}_{2}$ and parts of $\mathrm{CO}$ as well as the occurrence of $\mathrm{BO}_{4}^{3-}$ (after the gaseous emission of $\mathrm{B}$ compounds) indicate that the migrating gas is of volcanic origin, respectively of a geothermal anomaly (Freeth, 1992; Noll et al., 1996; Martini, 1993; Chiodini and Marini, 1998), but increased concentrations of $\mathrm{N}_{2}$ and $\mathrm{CH}_{4}$ are not completely understood, maybe methanogenese and denitrification are of some significance. The rising of volcanic gases through fractures beneath the lake bottom is an indication of volcanic or post volcanic activity and suggests the necessity for a more complex monitoring. However, gas sampling at the lake floor is still complicated, while for shallow areas the use of divers is helpful. In future, the monitoring of underwater volcanic activity has to be further developed, mainly for quantitative analyses of gases, the inflow of warm water, respectively hydrothermal water and the lake colmation. The detection of a new gas emission area between the islands with warm water springs demonstrates the need for monitoring.

Warm water inflow leads to heating of the lake. Despite the increased temperatures near the lake floor and the higher temperature in the western basin, the lake shows low temperature gradients, because the inflow of warm water in the $78 \mathrm{~m}$ basin is rapidly dispersed by billows formed with gas bubble rising.

\subsection{Hazard of $\mathrm{CO}_{2}$ accumulation in the lake}

In general, deep lakes $(>50 \mathrm{~m})$ with $\mathrm{CO}_{2}$ input possess a potential risk of limnic eruption, because under pressure a large amount of $\mathrm{CO}_{2}$ is soluble in water. The occurrence of increased $\mathrm{CO}_{2}$ concentrations in a volcanic lake depends strongly on mixing processes. This means that long term $\mathrm{CO}_{2}$ accumulation occurs only in amictic and meromictic lakes, while in mono- to polymictic lakes periodical degassing to the atmosphere reduces the $\mathrm{CO}_{2}$ concentration. Lake circulation behaviour depends on water density as a function of temperature and salt content, and is determined by heating of the epilimnion (increased stability of thermal 


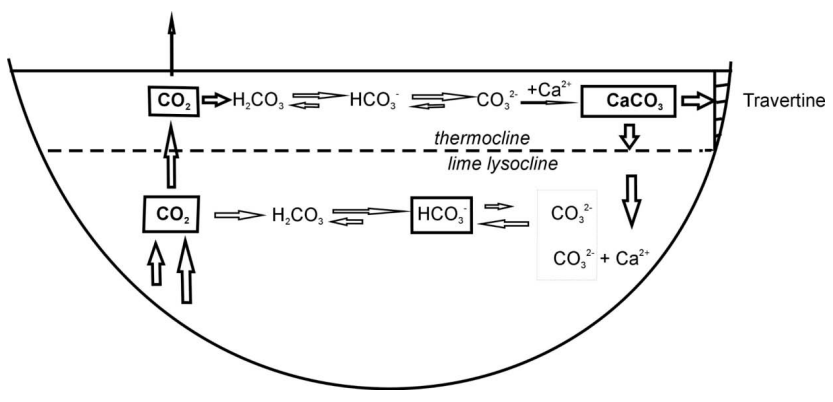

Fig. 14. Scheme of calcium and $\mathrm{CO}_{2}$ /hydrogen carbonate/carbonate cycling in Lake Cuicocha.

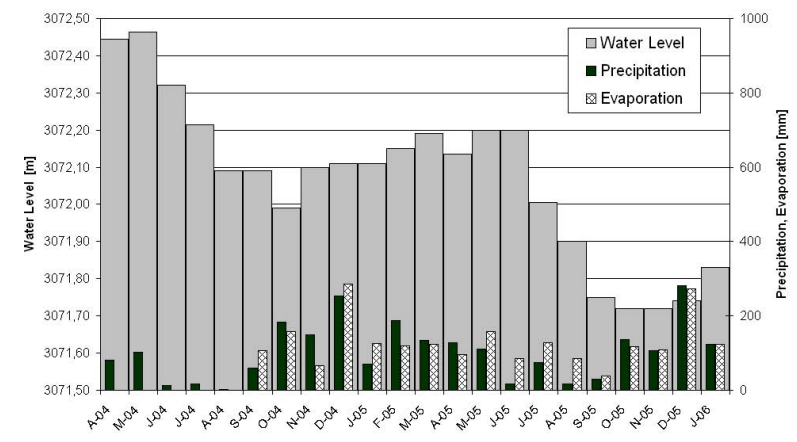

Fig. 15. Water balance of the Lake Cuicocha, evaporation was determined by water losses of a tank at the lake shore.

stratification), mixing processes due to wind or night cooling, and lake floor heating due to geothermal or hydrothermal effects (upwelling of heated water). Lake Cuicocha is a monomictic lake with a tendency to atelomixis processes, which means deep diurnal convergence currents by night cooling; this process was proved by results from the nearby lake Lago San Pablo (Gunkel and Casallas, 2002), being in a comparable climatic situation.

An accumulation of $\mathrm{CO}_{2}$ to a dangerous level does not occur in Lake Cuicocha, even when high amounts of $\mathrm{CO}_{2}$ are introduced into the lake. This is caused by the emission of gas bubbles and the turbulent exchange processes while rising, the inflow of warm water - may be of hydrothermal origin - alone would lead to a chemocline and the long time accumulation of dissolved ions and $\mathrm{CO}_{2}$.

Information about hydrothermal vents in lakes are very scare (Ronde et al., 2002); and hydrothermal venting with the build up of chimneys as it was observed in Lake Taupo (Ronde et al., 2002) were not found in Lake Cuicocha. The warm water rised up over a large area through pores and fissures in the lake bottom with simultaneous degassing.

A rough estimation of $\mathrm{CO}_{2}$ input (the difference in $\mathrm{CO}_{2}$ concentration in water between overturn and stratification periods) amounts to $3 \mathrm{t}$ per day or $3400 \mathrm{~m}^{3}$ pure $\mathrm{CO}_{2}$ gas per month at surface pressure, this value does not include perma- nent diffuse $\mathrm{CO}_{2}$ emission. Padrón et al. (2008) investigated this diffuse $\mathrm{CO}_{2}$ emission rate from Lake Cuicocha and calculated a flux of even $53 \mathrm{t}$ per day, being feasible due to the weak thermal stratification. This $\mathrm{CO}_{2}$ emission rate can be used to calculate the time needed to reach dangerous $\mathrm{CO}_{2}$ concentration in the lake if water mixing is hindered: in only 45 years the total hypolimnic water would have reach $\mathrm{CO}_{2}$ oversaturation and a triggered degassing, the limnic eruption can occur. This points out clearly the significance and need of a regular lake monitoring.

\section{Lake sediments and colmation processes}

Lake Cuicocha is a very young lake, only a few hundred years old, and therefore no nutrient accumulation has occurred, and sediment deposition level is very low; typical sedimentation rates in oligotrophic lakes amount to $<1 \mathrm{~mm}$ per year; the nearby eutrophic Lake San Pablo has a sedimentation rate of $3.5 \mathrm{~mm}$ per year (Gunkel, 2003). In many lakes, calcium carbonate precipitation is the main mechanism of sediment formation by so-called calcareous mud. In Lake Cuicocha this process is interrupted, and the Ca-carbonate saturation index points out clearly an oversaturation in the epilimnion with $\mathrm{CaCO}_{3}$ precipitation (down to $\sim 40 \mathrm{~m}$ ) and a Ca-carbonate undersaturation in the hypolimnion $(>40 \mathrm{~m})$ due to decreased $\mathrm{pH}$ as a consequence of $\mathrm{CO}_{2}$ emissions. Calcite formed in the epilimnion by primary production will be dissolved after sedimentation to greater depths. The calcium carbonate cycling process must be regarded as an internal source of $\mathrm{CO}_{2}$, too, under neutral to acid conditions. Calcite crusts at the shoreline and the lack of calcite deposits and shells from mussels and snails in the deposited sediments confirm this process.

In Lake Cuicocha the maximum sediment deposition of only a few decimetres since lake formation leads to a very fine colmation layer. This fine sediment layer cause many problems in sediment sampling, and information was obtained by using an underwater camera, together with the sediment corer. This technology confirmed a thin sediment layer on the stony floor, and in the western basin, holes without any sediment cover were observed between the rocks (Gunkel et al., 2008). These pores were probably formed by gas bubbles rising up and by sediment resuspension due to the gas bubbles, suspended sediments which reach the epilimnic zone will be transferred by wind induced currents and deposited in the $148 \mathrm{~m}$ basin of the lake.

In Lake Cuicocha a decrease in the water level of about $2 \mathrm{~m}$ in two weeks has been observed after the nearby earthquake of 5 March 1987, and a landslide of some $10000 \mathrm{~m}^{3}$ occurred. Since this event, a continuous water level decrease of about $30 \mathrm{~cm}$ can be observed by calcareous deposits above the water level as well as by a water gauge during the investigations period. Small fractures in the volcano must be still open and permanently cause water loss. Interaction between 
ground and surface water and pre-existing or uprising magma will usually result in the generation of stream-driven explosive activity (Mastin and Witter, 2000; Matthews, 2004), and recently coincidence of increased volcanic activity with intensive rainfall has been discussed on several volcanoes (Matthews et al., 2002; Matthews, 2004; Barclay et al., 2006). Up to now the significance of caldera lake colmation and lake water losses with pre-existing or uprising magma is less clear, but the percolation of lake water can lead to an increased risk of a phreato-magmatic eruption when it become contact to magma. The caldera of the volcano Cuicocha has been formed about 3000 years BP by an explosive process, and pyroclastic flows covered $180 \mathrm{~km}^{2}$ with a total volume of $4.1 \mathrm{~km}^{3}$, consisting mostly of dacite material (Mothes and Hall, 1991), which may indicate a geothermal activity. This possibility is supported by isotopes analyses $\left({ }^{2} \mathrm{H},{ }^{10} \mathrm{O}\right)$ of Lake Cuicocha water which show significant differences to the rain water line (von Hillebrandt, 1989) and too by the boron emission, indicating a high temperature reservoir for gas formation (Martini et al., 1994). Further investigations of lake colmation and regular monitoring of Lake Cuicocha heating, gas emissions and a hydrothermal activity must be carried out, together with volcanological monitoring.

Acknowledgements. This study is part of a cooperation project of the Technical University of Berlin, Germany, and the Central University of Quito, Ecuador, and was financed by the Deutsche Forschungsgemeinschaft, Germany (DFG, German Scientific Society) and the Ministry for Economic Development and Cooperation, Germany (BMZ). Support was provided by the National Park of Cotacachi, Ibarra, Ecuador, P. Casper, Leibniz-Institute of Freshwater Ecology and Inland Fisheries, Germany, and B. Hatton B. Sc., Cert. Ed. for the linguistic revision. Roberto Santamaria, GOE diver, placed many underwater pictures and films at our disposal.

Edited by: G. Macedonio

Reviewed by: one anonymus referee

\section{References}

Aguilera, E., Chiodini, G., Cioni, R., Guidi, M., Marini, L., and Raco, B.: Water chemistry of Lake Quilotoa (Ecuador) and assessment of natural hazards, J. Volcanol. Geoth. Res., 97, 271285, 2000.

Barclay, J., Johnstone, J. E., and Matthews, A. J.: Meteorological monitoring of an active volcano: Implications for eruption prediction, J. Volcanol. Geoth. Res., 150, 339-358, 2006.

Casallas, J.: Limnological investigations in Lake San Pablo, a high mountain lake in Ecuador, Dissertationsschrift, TU Berlin, Germany, 137 pp., 2005.

Casallas, J. and Gunkel, G.: Algunos aspectos limnológicos de un lago altoandino, el Lago San Pablo, Ecuador, Limnetica, 20, 29 46, 2002.

Chen, C. T. and Millero, F. J.: Precise thermodynamic properties for natural waters covering only the limnological range, Limnol. Oceanogr., 31, 657-662, 1986.
Chiodini, G. and Frondini, F.: Carbon dioxide degassing from the Albani Hills volcanic region, Central Italy, Chem. Geol., 177, 67-83, 2001.

Chiodini, G. and Marini, L.: Hydrothermal gas equilibria: The $\mathrm{H}_{2} \mathrm{O}-\mathrm{H}_{2}-\mathrm{CO}_{2}-\mathrm{CO}-\mathrm{CH}_{4}$ system, Geochim. Cosmochim. Ac., 62, 2673-2687, 1998.

Christenson, B. W.: Geochemistry of fluids associated with the 1995-1996 eruption of Mt. Ruapehu, New Zealand: signatures and processes in the magmatic-hydrothermal system, J. Volcanol. Geoth. Res., 97, 1-30, 2000.

Colt, J.: Computation of dissolved gas concentrations in water as functions of temperature, salinity, and pressure, Am. Fish. Soc., Spec. Publ., 14, 155 pp., 1984.

DEV: Bestimmung von Borat Ionen, Deutsche Einheitsverfahren zur Wasser-, Abwasser- und Schlammuntersuchung, Loseblattsammlung, Wiley, 6 pp., 1981.

DEV: DIN 38409-H7, Bestimmung der Säure- und Basekapazität, Deutsche Einheitsverfahren zur Wasser, Abwasser- und Schlammuntersuchung, Loseblattsammlung, Wiley, 28 pp., 2005.

Espinosa, A. F., Hall, M. L., and Yepes, H.: Tectonics and seismicity, in: The March 5, 1987, Ecuador Earthquakes - Mass Wasting and Socioeconomic Effects, Natural Disaster Studies 5, National Academy of Sciences, National Academy Press, Washington, DC, USA, 29-41, 1991.

Evans, W. C., White, L. D., Tuttle, M., Kling, G. W., Tanyileke, G., and Michel, R. L.: Six years of change at Lake Nyos, Cameroon, yield clues to the past and cautions for the future, Geochem. J., 28, 139-162, 1994.

Freeth, J. S.: Volcanic gases as a natural hazard, in: Natural hazards in West and Central Africa, Vieweg, Germany, 97-107, 1992.

Gunkel, G. and Beulker C.: Limnology of the crater Lake Cuicocha, Ecuador, a cold water tropical lake, Int. Rev. Hydrobiol., 94, 103-125, 2009.

Gunkel, G. and Casallas, J.: Limnology of an equatorial high mountain lake - Lago San Pablo, Ecuador: The significance of deep diurnal mixing for lake productivity, Limnologica, 32, 33-43, 2002.

Gunkel, G., Beulker, C., Gernet, U., Grupe, B,. and Viteri, F.: Aluminium in Lake Cuicocha, Ecuador, an Andean crater lake - Occurrence of dissolved and polymeric forms, Aquat. Geochem., submited, 2009a.

Gunkel, G., Beulker, C., Grupe, B., and Viteri, F.: Hazards of volcanic lakes: analysis of Lakes Quilotoa and Cuicocha, Ecuador, Adv. Geosci., 14, 29-33, 2008, http://www.adv-geosci.net/14/29/2008/.

Gunkel, G., Grupe, B., Viteri, F., and Beulker, C.: The Cuicocha/Cotacachi volcano complex (Ecuador): Recent history and secondary caldera manifestation, J. South Am. Earth Sciences, submitted, 2009b.

Gunkel, G.: Limnología de un Lago Tropical de Alta Montaña, Lago San Pablo-Ecuador: Características de los sedimentos y tasa de sedimentación, Revista Biología Tropical, 51, 381-390, 2003.

Hanuš, V.: Deep seismically active fracture zones in Ecuador and Northern Peru, Studia geoph. et geod., 31, 8-25, 1987.

Kling, G. W., Evans, W. E., Tanyileke, G., Kusakabe, M., Ohba, T., Yoshida, Y., and Hell, J. V.: Degassing Lakes Nyos and Monoun: Defusing certain disaster, P. Natl. Acad. Sci. USA, 102, 1418514190, 2005. 
Kusakabe, M., Tanyileke, G. Z., McCord, S. A., and Schladow, S. G.: Recent $\mathrm{pH}$ and $\mathrm{CO}_{2}$ profiles at Lakes Nyos and Monoun, Cameroon: implications for the degassing strategy and its numerical simulation, J. Volcanol. Geoth. Res., 97, 241-260, 2000.

Larson, G. L.: Geographical distribution morphology and water quality of caldera lakes A review, Hydrobiologia, 171, 23-32, 1989.

Le Guern, F. and Sigvaldason, G. E.: The Lake Nyos event and natural $\mathrm{CO}_{2}$ degasing I, Special issues, J. Volcanol. Geoth. Res., 39, 2-3, 1989.

Le Guern, F. and Sigvaldason, G. E.: The Lake Nyos event and natural $\mathrm{CO}_{2}$ degasing II, Special issues, J. Volcanol. Geoth. Res., 42, 4, 96 pp., 1990.

Martini, M., Giannini, L., Prati, F., Tassi, F., Capaccioni, B., and Ioizzelli, P.: Chemical characters of crater lakes in the Azores and Italy: the anomaly of Lake Albano, Geochem. J., 28, 173184, 1994.

Martini, M.: Gases volcánicos y eventos eruptivos, in: La volcanología actual, Consejo Superior de Investigaciones Científicas, Madrid, 387-444, 1984.

Martini, M.: Gases volcánicos y eventos euptivos, in: La volcanología actual. Consejo Superior de Investigaciones Científicas, Madrid, 387-444, 1993.

Mastin, L. G. and Witter, J. B.: The hazards of eruptions through lakes and seawater, J. Volcanol. Geoth. Res., 97, 195-214, 2000.

Matthews, A. J., Barclay J., Carn, S., Thompson, G., and Alexander, J.: Rainfall-induced volcanic activity on Montserrat, Geophys. Res. Lett., 29, 13, 22-1-22-4, 2002.

Matthews, A. J.: A thermodynamical model for rain-fall-triggered volcanic dome collapse, Geophys. Res. Lett., 31, L05614, doi:10.1029/2003GL019310, 2004.

Moss, S. A. and Nagpal, N. K.: Ambient Water Quality Guidelines for boron, Ministry of Water, Land, and Air Protection, British Columbia,ISBN:0-7726-5048-9, 112 pp.2003.

Mothes, P. and Hall, M. L.: El paisaje interandino y su formación por eventos volcanicos de gran magnitude, Estudios de Geografía, 4, 19-38, 1991.

Noll Jr., P. D., Newsom, H. E., Leemann, W. P., and Ryan, J. G.: The role of hydrothermal fluids in the production of subduction zone magmas: Evidence form siderophile and chalcophile trace elements and boron, Geochim. Cosmochim. Ac., 60, 587-611, 1996.
Ostrovsky, I., McGinnis, D. F., Lapidus, L., and Eckert, W.: Quantifying gas ebullition with echosounder: the role of methane transport by bubbles in a medium-sized lake, Limnol. Oceanogr.Meth., 6, 105-118, 2008.

Ostrovsky, I.: Methane bubbles in Lake Kinneret: Quantification and temporal and spatial heterogeneity, Limnol. Oceanogr., 48, 1030-1036, 2000.

Padrón, E., Hernández, P. A., Toulkeridis, T., Pérez, N. M., Marrero, R., Melián, G., Virgili, G., and Notsu, K.: Diffuse $\mathrm{CO}_{2}$ emission rate from Pululahua and the lake-filled Cuicocha calderas, Ecuador, J. Volcanol. Geoth. Res., 176, 163-169, 2008.

Pasternack, G. B. and Varekamp, J. C.: Volcanic lake systematics I, Physical constraints, B. Volcanol., 58, 528-538, 1997.

Robin, C., May, M., Jiménez, M., Monzier, M. and Escobar, P.: Mojanda volcanic complex (Ecuador): development of two adjacent contemporaneous volcanoes with contrasting eruptive styles and magmatic suites, J. South Am. Earth Sciences, 10, 345-359, 1997.

Ronde, C. E. J., Stoffers, P., Garbe-Schönberg, D., Christenson, B. W., Jones, B., Manconi, R., Browne, P. R. L., Hissmann, K., Botz, R., Davy, B. W., Schmitt, M., and Battershill, C. N.: Discovery of active hydrothermal venting in Lake Taupo, New Zealand, J. Volcanol. Geoth. Res., 115, 257-275, 2002.

Scheffer, F. and Schachtschabel, P.: Lehrbuch der Bodenkunde, 12, neubearb. Aufl., Enke, Stuttgart, Germany, 491 pp., 1989.

Schoell, M., Tietze, K., and Schoberth, S. M.: Origin of methane in Lake Kivu, East-Central Africa, Chem. Geol., 71, 257-265, 1988.

VDLUFA: Die Untersuchung von Böden, Bd. 1, 1.+2., Teillieferung, VDLUFA Verlag Speyer, Darmstadt, Germany, 1470 pp., 1991.

von Hillebrandt, C. and Hall, M. L.: Mapa de los Peligros Volcánoicos Potenciales Asociados con el Volcán Cuicocha. Esc. 1:50000, Escuela Politécnica Nacional, Quito, Instituto Geográfico Militar,1 p., 1988.

von Hillebrandt, C.: Estudio geovulcanologico del complejo volcanico Cuicocha - Cotachachi y sus aplicaciones, Provincia de Imbabura, Thesis Magister Geologia, Escuela Politecnica Nacional, Quito, Ecuador, 210 pp., 1989.

WHO: Guideline for Drinking Water Quality, WHO, Genera, 3rd edn., ISBN:92-4-154638-7, 515 pp., 2004.

Zehetner, F., Miller, W. P., and West, L. T.: Pedogensis of volcanic ash soils in Andean Ecuador, Soil. Sci. Soc. Am. J., 67, 17971809, 2003. 